\title{
David Hume and contemporary realism in political theory
}

Author: Björn Östbring 


\section{Abstract}

Proponents of the recent movement of realism in political theory have expressed dissatisfaction with the typically Kantian and ideal theoretical assumptions that guide much political and normative theorizing. In this paper it is proposed that these realist theorists could find support for their critique of the Kantian legacy, as well as building blocks for a realist alternative, by drawing on the moral and political thought of David Hume. The paper constitutes a reading of Hume's writings with the contemporary realist critique in mind. The result highlights four themes in Hume's thought: (1) The empirically informed approach to normative reasoning. (2) An emphasis on that political theorizing must be conducted on the basis of a realistic political psychology. (3) The critique of social contract doctrines, a critique that is directed at idealistic and rationalistic versions of liberalism. (4) Hume's account of human sociality and the origins of political authority. Lastly, it is suggested that the fact that Hume combines realism with liberalism makes him of additional interest to the many realists who are seeking to correct rather than reject liberal political theory and who are thus wary of finding themselves too close to Machiavelli and Hobbes, the usual realist predecessors.

Key words: realism, moralism, ideal theory, legitimacy, normativity Length: 19200 words 


\section{Table of contents}

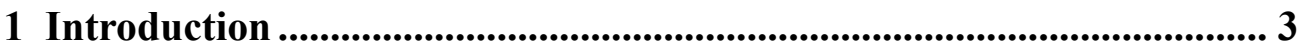

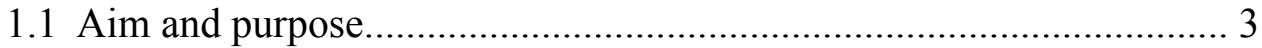

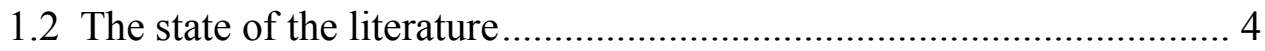

1.3 The disposition, and two caveats.................................................... 5

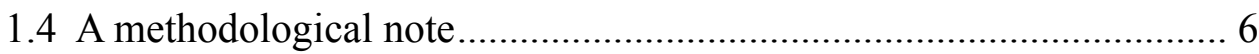

2 Realism and moralism in political theory ….............................................. 8

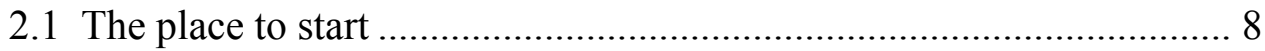

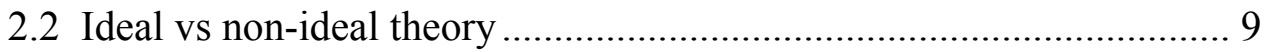

2.3 Liberal legitimacy and the autonomy of politics.............................. 10

3 Hume as non-ideal theorist............................................................... 13

3.1 'Is' and 'Ought': Hume and normative theory ................................... 13

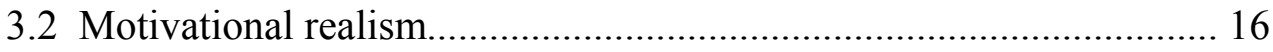

4 Hume as theorist of political order ....................................................... 20

4.1 The critique of contract theory .......................................................... 20

4.2 Human sociality and the origins of government ............................... 24

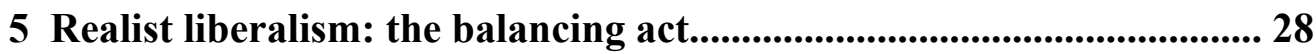

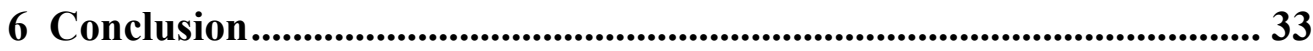

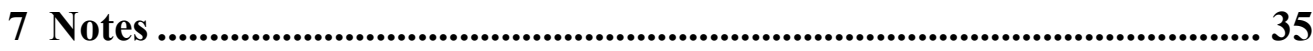

8 Executive summary ........................................................................................ 39

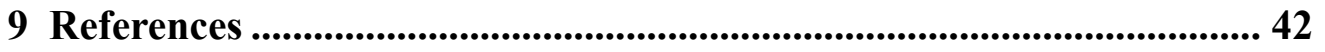




\section{Introduction}

In recent years there has formed a movement of political theorists that is united by their critique of the dominant mode of conducting political theory as exemplified by John Rawls and Ronald Dworkin. Critics like Bernard Williams, Raymond Geuss, and William Galston have all accused major parts of contemporary political theory for being "unrealistic". Their targets are the practitioners of a mode of political theory which stem from Kant, and which according to its critics is too abstract and too removed from empirical realities of political life and human nature. The critics, ${ }^{1}$ while clearly writing from different perspectives, have enough in common to warrant a common label; at least that is argued by Richard North, editor of a recent special issue of European Journal of Political Theory devoted precisely to this movement of "realism" in political theory (North 2010). ${ }^{2}$ But if a great deal of contemporary political theory is written in the vein of Kant, is there similarly a historical counterpart for the realist critics? Realists are typically influenced by Machiavelli and Hobbes, but neither of these offers an alternative as comprehensive as the Kantian legacy. The starting point of the present paper, however, is the hunch that David Hume's moral and political philosophy may provide the disparate school of realist theorists with such a common historical predecessor and source of arguments and ideas.

\subsection{Aim and purpose}

In this paper I will argue that some of the realists' key ideas can be identified or reconstructed in the political thought of Hume. I will begin the paper with a description of the realist critique of contemporary political theory, and proceed with a survey of Hume's writings ${ }^{3}$ in search of arguments and reflections that have bearing on that debate. As a guide to realism I will primarily rely on Galston's overview (Galston 2010), which will be used as a companion throughout the paper in the attempt to establish where Hume take a similar stand or employ arguments that ought to interest contemporary realists. The primary aim of the study is to bring out the connections and similarities between the recent movement towards "realism" in the field of political theory and the moral and political thought of David Hume. The general purpose behind this aim is to show how a kind of Humean mode of political theory might be the way for realists to construct a viable and attractive alternative to the Kantianism that dominates contemporary political theory.

This purpose naturally raises the question of Hume's current place and reputation in contemporary political theory. Angela Coventry and Alex Sager writes: 
Hume occupies a central, but ambiguous position in contemporary political philosophy. Political philosophers recognize the importance of his analysis of justice as an artificial virtue and his account of convention, his identification of the "conditions of justice," and his criticisms of the social contract. But while it is fairly easy to identify philosophers with acknowledged Aristotelian, Hobbesian, Lockean, Kantian, and Hegelian approaches to political philosophy, Hume has no school and few disciples. (Coventry \& Sager 2011: 1)

Regarding the lack of a Humean "school of thought" in political philosophy, I will suggest that if such a school were to develop it ought to have a realist bend. But I would like to repeat that the aim of the paper is not to provide an interpretation of Hume's thought designed to satisfy a historian of ideas; the focus is not on Hume and his legacy, but on contemporary realists and their interest in finding an alternative to Kantian political theory. So the claims in this paper is not primarily intended as an historical interpretation, but rather to highlight what use Hume's thoughts could be put to by modern realists.

\subsection{The state of the literature}

Is the topic and questions outlined above entirely new and unexplored? What do we find in the existing literature; what connections between contemporary realism and Hume do we find? In the camp of contemporary realists no theorist explicitly draws on Hume. Naturally they often cite Hobbes and Machiavelli, but Hume seems not to be an important influence on any of the theorists in the realist camp. This neglect is the primary motivation behind this paper. The only possible exception would be the philosopher Bernard Williams: while his writings in political philosophy do not contain any reference to Hume, his ethical thought display an important Humean influence (Greco 2007). Bernard Williams is of special interest for this paper since his book In the Beginning was the Deed (2005) is generally regarded as the starting point for the revival of realism among contemporary theorists (North 2010: 383; Sleat 2010: 485-86).

In the other camp, among those writing on Hume's thought, there is at least one theorist who has highlighted the realist elements of Hume's thought. Frederick Whelan (2004) has traced Machiavelli's influence on Hume, and argues that this side of Hume's thought has been long neglected (Whelan 2004: 1-2). Hume's thought is characterized by typically realist themes: his writings are "historical rather than abstract", he had a "strong sense of the limits of rationalism in social life", and as a historian he knew better than most that liberal regimes "are rare and precarious" (Whelan 2004: 2, 7). Since contemporary political theory is dominated by the heirs of Locke and Kant, the purpose of Whelan's book is to make room for a more realistic style alongside the idealistic forms of political theory (2004: ix, 1-2).

In the present paper I basically take up from where Whelan leaves off. In the final pages of his book Whelan discuss more generally the possibility of a tradition of realist thought, and points to some contemporary theorists who, like 
Hume, strive to combine ethical engagement with realist sense of possibility and caution: Isaiah Berlin, Stuart Hampshire, Judith Shklar, and Bernard Williams (2004: 339-354). But Whelan's section is brief on this topic, and his book was written before the movement of realism had gathered its present momentum. I must acknowledge a significant debt to Whelan's study, for I have greatly benefitted from his tracing of the Machiavellian and realist elements of Hume's thought. To repeat, this paper is intended to build on Whelan's realist interpretation of Hume, by focusing more on what contemporary realists stand to gain by studying Hume given such an interpretation of his thought.

\subsection{The disposition, and two caveats}

We have now everything in place to consider the structure of the paper. Chapter 2 is a description of the realist movement, such as it is advocated by Bernard Williams (2005), Raymond Geuss (2008) and William Galston (2010). More specifically, section 2.2 introduces the contemporary debate on ideal vs non-ideal theory, and the realists' critique of ideal theoretical assumptions is presented. The chapter ends with (section 2.3) a description of the second frontline between realists and liberal "moralists", namely the account and importance of legitimacy: in this debate the realists challenge the dominant liberal view that the use of political power must be made justified to all persons subject to that power. Here, I suggest, is also the basis for the realists' insistence on the autonomy of politics. Chapter 3 and 4 contain the bulk of the essay: several main features of Hume's philosophy and political thought are highlighted as having a realist character or being of interest to realists. In chapter 5 I change gear. On the assumption that I have successfully established the existence of many realist themes in Hume's thought, I turn to the issue of combining realism with liberalism. The point of this chapter is to strengthen the case for Hume's relevance and importance. As he is a liberal thinker, he potentially offers more guidance to the many realists that would like to combine realism with liberalism; guidance they cannot find in their usual sources of inspiration, Machiavelli and Hobbes.

Two caveats are in order. First, readers may find that I move too quickly over important and difficult questions. For sure, each of the themes could be made a topic for a separate paper. Yet I have chosen to move swiftly over a larger territory, which I think is the only way to fulfill the stated purpose. It is precisely the fact that several realist themes can be found in Hume that is the basis for the claim that Hume could be seen as a major historical predecessor and potential source of inspiration. The paper has, like Galston's piece, the character of a bricolage (Galston 2010: 386), which means that I will let Hume and the realists speak for themselves, and only put together the different pieces and make a suggestion of how they may fit together. ${ }^{4}$ Since the purpose requires me to establish several philosophical connections, brevity is required; this in turn means that the paper will have the character of merely charting the outlines of a research topic hitherto neglected. 
The second caveat. The movement of realism is a loose one; Galston for instance describes it as being "a community stew" where theorists bring different ingredients to the pot (Galston 2010: 386). This means that while Galston intends with his article to "connect the dots", we should not think of realism as a package deal that one either buys into or not. This has an important implication. When I write sentences like "A realist thinks that...", then this should be understood as "A realist on this particular issue thinks that...". It makes sense to delineate "realist positions" on many topics without thinking that a realist theorist is obliged to share all of those views. Indeed, "the realist" that I will speak of throughout the paper is an extrapolation: an imagined thinker that happens to take a realist stand on all of the issues under discussion.

\subsection{A methodological note}

The aims and approach of this paper naturally raise methodological questions regarding interpretation of historical texts and the possibility of comparing ideas from vastly different historical contexts. Methodologically, what this paper stands in need of is a defense of the possibility of such an "unhistorical" approach. Can we really be so frivolous as to let Hume speak to present theoretical concerns or political problems without firmly establishing the political and philosophical context of his writings? I would like to answer 'yes' to that question. But in order to do so I need to consider the claims of the proponents of the Cambridge school. Historians like Quentin Skinner and John Pocock have long since established a school of interpretation in which it is regarded as a vain venture to approach past political thinkers with an eye to what they have to say to present concerns, or of studying purported "perennial questions" of political philosophy. We cannot understand the writings of these historical thinkers without a close eye to the context in which they were written, regarding the texts as interventions in debates that are local in time and space, and having as purpose to convince specific people to change their views or make certain practical decisions (Pocock 2009: 67-68, 81-82). These interventions are to be seen as 'moves' in the language game that is in use for talking about politics. A consequence of this view is that studying "minor" authors become more important, since it is they who set the debate that the "major" author is responding to, and thus they hold the key to the proper meaning of the major text.

It is easy to see that such a methodological stance is incompatible with the aims of this paper. Constructing a "tradition" of realist thought, and transferring ideas from one historical context to another, is precisely what the Cambridge historians criticized. Authors taking this line would strive to avoid placing thinkers and ideas in "traditions" or "schools" of thought (e.g. Keene 2005: 3-5). The reluctance follows from a rejection of the idea of the perennial character of the problems of the discipline. If there is no continuity of subject matter, there is unlikely to be a continuity of similar theories. Hence, to proclaim a "tradition" of a certain kind is often to invent similarities that do not exist. 
In response, what I would like to defend is the modest line taken by Pasquale Pasquino. He does not deny that it is necessary "to keep in mind that most of the time the author is trying to persuade a specific public to make certain practical choices" (Pasquino 1996: 22). Yet it is also undeniable that the great historical works of political theory "continues to provide food for thought for a much larger public than that for which it was written", and in that sense the contextual dimension "does not exhaust the significance of the text" (1996: 22). It simply remains that these texts make sense to us today. Hume's attempt to educate "sound political opinions", by criticizing the philosophical presuppositions behind immoderate and dangerous political opinions, can still be read and appreciated today; they may still provide food for thought for those of us who are of a contemplative bent in matters political.

There is a lot to be said for the historians' case against the more lighthearted approach of political theorists who treat past thinkers as fundamentally engaged in the same debate. Yet it is an open question which conclusion is to be drawn. As Michael Frazer points out in reviewing a volume of Pocock's essays:

Yet if gaining wisdom from great books is fundamentally unhistorical, perhaps the proper response is to conclude, "Well, so much the worse for history". (Frazer 2009)

This suggestion may sound frivolous. Yet Frazer raises a reasonable question, since at the other end of the spectrum lies the risk of an excessive scholarly antiquarianism (Gunnell 1982: 327). A Cambridge school historian's approach to the study of the political thought of past thinkers may effectively negate the grounds we had for our initial interest in these works, namely that they have something to say to us here and now (Frazer 2009).

The crucial question, however, is whether the Cambridge approach can disqualify all other approaches? Does their approach "exhaust the significance of the text", as Pasquino doubted? Do we need to go as far as holding that we cannot usefully think of the authors' writings as having meaning and bearing in other contexts? I agree with Mark Philp who argues that:

[T] here remains a core set of concerns that mark political activities off from other activities and provide the basis for a sense that there are continuities in the discussion that revolve around political rule and the attempt to exercise political authority. (Philp 2008: 137)

If we think of historical texts of political theory as so bound by context that no translation to other contexts is possible, then their authors would have little to say to us. The "core set of concerns" is the bridge that enables translation. The historians may demur, but the discipline of political philosophy depend on such translation, and to the extent that the discipline is a legitimate pursuit at all, it is simply unreasonable "to think that good political philosophy is something for which meeting the criteria for good history is a necessary and sufficient condition" (Philp 2008: 138). 


\section{Realism and moralism in political theory}

\subsection{The place to start}

There are two particular thinkers which any overview of realism must take as a starting point: Bernard Williams and Raymond Geuss have each provided critiques of what they see as the "moralism" of the dominant strands of contemporary political theory. They both claim the priority of politics over morality. Raymond Geuss's book Philosophy and Real Politics (2008) is a criticism of what he calls the 'ethics-first' approach in political theory. This approach is a particular understanding of the slogan "Politics is applied ethics", a view of how ethics and ethical judgments relate to politics. In particular it is "a theory about where one should start in studying politics, what the final framework for studying politics is, what it is reasonable to focus on, and what it is possible to abstract from" (Geuss 2008: 6). These are themes and questions which all realists raise against their opponents, but Geuss' account is the first book-length exposition of a realist critique. ${ }^{5}$

A key point of criticism regards the idea that we should or even could start theorizing by considering or proposing an "ideal theory" in the realm of ethics, quite undisturbed by the theories and findings in the fields of sociology, psychology, history or economics. This evasion of the empirical is typically combined with a high degree of abstraction and systematization. The prime example of this style of theorizing is Kantianism, according to Geuss, since it assumes that ethics "can be completely nonempirical" and that its principles hold sway under all historical circumstances (2008: 7). Kantianism is thus an example of an 'ethics-first' view:

\footnotetext{
The view I am rejecting assumes that one can complete the works of ethics first, attaining an ideal theory of how we should act, and then in a second step, one can apply that theory to the actions of political agents. As an observer of politics one can morally judge the actors by reference to what this theory dictates they ought to have done. Proponents of the view I am rejecting then often go on to make a final claim that a "good" political actor should guide his or her behaviour by applying the ideal theory. The empirical details of the given historical situation enter into consideration only at this point. "Pure" ethics as an ideal theory comes first, then applied ethics, and politics is a kind of applied ethics. (Geuss 2008: 8-9)
}

What Geuss is criticizing is (a species of) what the late Bernard Williams would have called "moralism" in political theory. While Williams didn't manage to complete his planned book in political philosophy, his papers and essays on these topics have been posthumously published (Williams 2005), and they now form an important source for realist political theory. 
Moralism, according to Williams, comes in two varieties. Both of them, but in different ways, "make the moral prior to the political" (2005: 2). One is structural models in which the bounds and conditions for a legitimate political order and exercise of power are set through prior and purely moral reflections. Williams notes that in Rawls' theory of justice the goal of achieving distributive justice is not presented as simply a desirable goal: it is "presented less in terms of a programme, and more in terms of a required structure" (2005: 1). The second variety is enactment models - utilitarianism being the prime example - in which politics is seen as a project for enacting and realizing those principles, ideals and values that is dictated by the moral theory in question, thus reducing politics to being "the instrument of the moral" (2005: 2). Political moralism thus put moral theory prior to politics and above considerations of political circumstances, either by proposing moral constrains (typified by Kant's famous dictum that "All politics must bend its knee before the right"), or by antecedently setting the goals towards which politics is regarded merely as questions of means. In both cases political theory is regarded as "something like applied morality" (2005: 2).

This moralism Williams contrasts with "political realism", a way of theorizing which "gives a greater autonomy to distinctively political thought" (2005: 3). ${ }^{6}$ All theorists drawn together in the realist camp can be said to share the inclination to take politics more on its own terms. Often quoted is Bonnie Honig's claim that contemporary political theory is characterized by "the displacement of politics" (Galston 2010: 386; North 2010: 382; Sleat 2011: 473-74; Williams 2005: 58). Realists would like to bring the realities of politics and the moral failures of citizens and politicians back to the attention of political theorists. Such considerations, rather than what justice would be like under ideal circumstances, ought to be their main focus. In surveying the recent literature one may discern two main issues where realists press this point. These will be discussed in the two following sections.

\subsection{Ideal vs non-ideal theory}

Realists naturally take side in the fierce debate within contemporary political theory regarding the appropriate assumptions regarding individuals and their motivations and actions, as well as assumptions of the general features of society in which they act. The realists" complaints about "moralism" make them critical of what is called "ideal theory".

The distinction between ideal and non-ideal theory stem from Rawls, who himself is a (moderate) practitioner of ideal theory. In Rawls' theory of justice a "well-ordered society" is assumed, which certainly is an ideal assumption. Secondly, everyone in this society "is presumed to act justly and to do his part in up-holding just institutions" (Rawls 2005: 8). This assumption is called "full compliance" and is a defining feature of ideal theory. Full (or 'strict') compliance means that all agents will act in accordance with the normative principles that the theorist is considering. 
Realists doubt that theorizing on such contrary-to-fact assumptions is worthwhile. The assumption of full compliance distances the theorist, by conceptual necessity, from the most pressing normative questions. For these questions often consist exactly in problems of how to deal with those who do not comply. Here we have a clear difference between the sphere of individual morality and that of politics. To take an example: We might as a moral rule propose that the use of violence is wrongful, but would we then, on that ground, draw the conclusion that institutions such as a police force and jails are illegitimate since coercion is part of their very nature? As Burke Hendrix says, we generally do not draw this conclusion and the reason is quite simple: Since we know that not everyone will follow the moral rule not to use violence, we thus "will want to plan for these moral failures when they occur" (Hendrix 2010:3).

So on ideal-theoretical assumptions many of our institutions would not make sense, nor would many ordinary moral questions and dilemmas. In contrast, as Colin Farrelly argues, non-ideal theory is where the action really is: Normative theorists must here face the real world where such things as selfish and wicked behavior, deep disagreement, budget constraints, and limited knowledge must be reckoned with (Farrelly 2007: 857-861). By assuming too favorable circumstances and too well-intentioned and principled citizens, political theorists spend their intellectual efforts on comparably unimportant disputes regarding what justice would be like in an ideal world.

This is a sentiment shared by realists. As Galston says, realists put institutions and actual behavior at the center, at the expense of debating the finer point of the Difference Principle (2010: 393-94). For the crucial questions to face are the ones of limited compliance, limited altruism, irrational behavior, scarce resources, and so on. In such a world, theorists must never lose sight of the fallible constructs known as institutions, through which humans must arrange their common life. Realists typically would like to return to a classical mode of political theory, a wish here put in words by Philip Pettit:

Many of the classic texts in political theory, from Machiavelli's Discourses to Montesquieu's Spirit of the Laws [...] to Mill's Considerations on Representative Government deal with how institutions should be ordered in the real world of parochial bias, limited resources, and institutional and psychological pathology... [I]t is little short of scandalous that this area of work is hardly ever emulated by political philosophers today. (Philip Pettit, quoted in Galston 2010: 394)

\subsection{Liberal legitimacy and the autonomy of politics}

At a general level, a realist critic basically argues that political theory ought to be more fact-sensitive. The empirical realities of the social world cannot be abstracted away if the normative claims that the theorist put forward should be taken to have force for persons living in that world: "the issue for us will always be about what to do under non-ideal conditions" (Horton 2010: 436). This critique of ideal theory is directed at large parts of contemporary political theory. But we 
can usefully end this summary of realism with a specific application or elaboration of this theme.

Many realists have ventured to strike specifically against the traditional liberal account of political legitimacy, which is at the heart of liberalism itself. The liberal view is that a political order is only legitimate if it is consented to by those over whom power is exercised. Legitimate power depends on the consent of the persons subject to it. So when the liberal theorist discuss the proper principles and bounds of a political order, they frame the questions in terms of what can be justified or consented to by all persons. The search for the answer to this question thus become the prime task of political theory and the only way to settle disputes on what is legitimate for a political order (Sleat 2011: 471-72).

But what happens if we press the empirical point that consensus is not likely to occur; that disagreement is pervasive and hence that it might be impossible to justify one particular political order to each and everyone? One defining feature of the realist critique is that it tries to drive this point home. Realists are theorists of what Stears (2007) call "the politics of compulsion", which question the standard liberal view of coercion and legitimacy. On this view, the fundamental facts of social life are such that coercion can never be expected to disappear, or that it is obvious or that coercion is purely a negative phenomenon (Stears 2007: 541).

The consensus or agreement on political fundamentals, which the liberal demands, is never to be expected. Some realists hold that consensus is a "theoretical chimera", while others believe that though agreement may be possible it is then precisely the product of politics - and certainly not to be found prior to its processes (Sleat 2011: 474). The problem with liberal theory is that it looks for consensus at the root, and sets it as a requirement for politics to even get off the ground. On the realist view, in contrast, disagreement is the inevitable starting point, and politics "is best understood as the functional response to that disagreement" (Stears 2007: 745).

At this point we also find an important argument for the possibility of "distinctively political thought". To be a credible alternative to "moralism", it is essential for realists to put more meat on the elusive notion of "the priority of politics". Only if the political sphere can be said to involve activities and relationships of a special kind, it will be possible to have a normative but truly political theory, i.e. not a political theory of the ethics-first view in which an ethical doctrine is merely enacted or applied.

\footnotetext{
If political theorists simply apply exogenous morality to politics, we have a quasi-Kantian picture in which "all politics must bend its knee before the right." But if theorists discover moral principles by examining politics as a distinctive sphere of human activity, then political theory may well have a distinctive, though still recognizably moral, content that cannot be derived from non-political morality. (Galston 2009: 88)
}

So a lot hinges on whether political life really can be understood as a distinctive sphere. If it can plausibly be described as autonomous, then we have a case for rejecting the ethics-first view. In their critique of liberal legitimacy, it becomes clear that realists have a view of politics as essentially and inevitably contested. At the root of this contention seems to lie a particular view of human nature. 
Realists typically share Aristotle's view of man as a social being. Yet the forms of cooperation and coordination are not "hard-wired" in her constitution. Galston calls this fact "unscripted sociality" (2010: 390). If this is so - if humans depend on social interaction and coordination while the forms and rules of such behavior are not scripted in her nature - then politics can be seen as the arena in which terms of cooperation and forms of coordination are set. For if cooperative behavior is not hard-wired into humans, they must face the question of how to deal with those who don't cooperate and who thus thwart collective efforts or the coordination attempted by others. In this vein, we may view politics naturalistically as a phenomenon that arise in order to deal with what we perhaps would like to describe as the social deficiencies of human nature. 


\section{Hume as non-ideal theorist}

\section{1 'Is' and 'Ought': Hume and normative theory}

First of all we must consider an important reason why some may question the key thesis of this paper. The doctrine which Hume is today perhaps mostly famous for is the thought that it is impermissible to reason from an 'is' to an 'ought'. And that doctrine may constitute a major reason for finding it strange to align Hume with the realists, and for questioning whether the empirically-informed political theory which realists argue for really can be defended in Hume's philosophy. For the is/ ought-passage, which have come to be called "Hume's law", can seem to be at odds with one central realist claim, namely that we should strive to narrow the gap (or blur the distinction) between the normative and the empirical. So in this regard Hume could actually be understood as being on the same side as Kant, and being equally the target for realist critique. Raymond Geuss describes his realist project as fundamentally opposed to the distinctions which Hume's law is usually taken to insist on:

I do not distinguish sharply between a descriptive theory and a "pure normative theory" (the former purportedly giving just the facts the latter moral principles, imperatives, or ideal norms). This is fully intentional, and indeed part of the point I am trying to make. I want precisely to try to cast as much doubt as I can on the universal usefulness of making these distinctions. Kantians, of course, will think I have lost the plot from the start; and that only confusion can result from failure to make these essential, utterly fundamental divisions between Is and Ought, Fact and Value, or the Descriptive and the Normative. (Geuss 2008: 16)

An adherence to Hume's law may lead one to suspicion about the empiricallyinformed normative analysis that Geuss recommends. Unsurprisingly, the kind of abstract and ideal theorizing that realists are criticizing is sometimes defended by an invocation of Hume (Frazer 2010: 7, 174). Galston too has diagnosed the wedge between normative theory and empirical inquiry, which he and other realists find lamentable, as being part of Hume's legacy, which in contemporary philosophy has taken the form of warnings of the so-called naturalistic fallacy (Galston 2004: 90).

So what did Hume say? Lets take a look at the passage in the Treatise that contains what is now called Hume's law.

I cannot forbear adding to these reasonings an observation, which may, perhaps, be found of some importance. In every system of morality, which I have hitherto met with, I have always remark'd, that the author proceeds for some time in the ordinary way of reasoning, and establishes the being of a God, or makes observations concerning human affairs; when of a sudden I am surpriz'd to find, that instead of the usual copulations of propositions, is, and is not, I meet with no proposition that is not connected with an ought, or an ought not. This change is imperceptible; but is, however, of the last 
consequence. For as this ought, or ought not, expresses some new relation or affirmation, 'tis necessary that it shou'd be observ'd and explain'd; and at the same time that a reason shou'd be given, for what seems altogether inconceivable, how this new relation can be a deduction from others, which are entirely different from it. (Treatise: 3.1 .1 .27 )

The standard interpretation of this passage is that Hume here argues that "no set of nonmoral premises can entail a moral conclusion", and it is this interpretation that is usually meant when one speaks of "Hume's law" (MacIntyre 1959: 452). Thus understood, Hume becomes an opponent of attempts to find "foundations" of morality which is not itself moral, and thus also "an exponent of the autonomy of morality" in the same manner as Kant (MacIntyre 1959: 452). This interpretation of the is/ought passage is still today part of the "default understanding" of Hume's metaethical views, "one that has shaped the way in which most readers of Hume who have a philosophical education read his text" (Cohon 2008: 11).

But is this the correct way of understanding Hume's passage? Those who have drawn upon Hume for a belief in the importance of the naturalistic fallacy most certainly have made an interpretation of the above passage that is at odds with the character of Hume's general philosophy. As Alasdair MacIntyre has said, if Hume's law is taken on the standard interpretation, "then the first breach of Hume's law was committed by Hume; that is, the development of Hume's own moral theory does not square with what he is taken to assert about 'is' and 'ought'" (MacIntyre 1959: 452). If the common reading of the passage is correct, we would be forced to conclude that many of Hume's other discussions are "puzzling, sloppy, conceptually discontinuous, fallacious, self-contradictory, or in conflict with other parts of his philosophy" (Cohon 2008: 12).

Can another interpretation be given which saves Hume from inconsistency? We will soon turn to MacIntyre's own suggestion. But first, let me clarify the purpose of the present section for the paper as a whole. I should make clear that the purpose is primarily "defensive". I want to cast doubt on the possibility of using "Hume's law" as an argument against the central claim of this paper; i.e. to use it against the attempt of aligning Hume with the realists' insistence on empirically informed normative theorizing and their critique of the more abstract and free-standing alternative way of thinking. Like MacIntyre, my hope is precisely to "prevent Hume from being classified with [Kant]" on the issue of the autonomy of normative theory (MacIntyre 1959: 463). The significance of this issue is obvious. To the realists engaged in the debate on the autonomy of moral philosophy it is important to know which historical thinkers they are up against. And to the present paper it is important that Hume is not one of them.

MacIntyre goes on to say that it would be "very odd" if Hume intended what contemporary philosophers think he did, since that doesn't square with the amount of sociological and psychological analysis that the Treatise contains; the occupation with "the facts of morality" in Hume's work create a very marked difference of atmosphere from that of the moral philosophers who have adopted Hume's law and who conduct moral philosophy in a more abstract and rationalistic manner (MacIntyre 1959: 455). Can MacIntyre solve the puzzle with a credible interpretation? 
The main strategy he deploys is to question the correctness of the assumption that the relation between 'is' and 'ought' must be one of entailment. On such terms it is indeed impossible to move from 'is' to 'ought', but MacIntyre question whether the entailment relation is the only possible one, or rather, whether Hume actually thought so. There are weaker forms of inference (and there is evidence that the term 'deduction' was not in Hume's time a synonym to logical entailment (1959: 460-61), and crucially, there are some notions whose very existence questions the neat division between facts and values.

\begin{abstract}
We could give a long list of the concepts which can form such bridge notions between "is" and "ought": wanting, needing, desiring, pleasure, happiness, health - and these are only a few. I think there is a strong case for saying that moral notions are unintelligible apart from concepts such as these. The philosopher who has obscured the issue here is Kant whose classification of imperatives into categorical and hypothetical removes any link between what is good and right and what we need and desire at one blow. (MacIntyre 1959: 463)
\end{abstract}

On this understanding the is/ought passage becomes consistent with the defining features of Hume's moral philosophy, here described by Stuart Hampshire:

\footnotetext{
Hume's philosophy encourages the smooth transition from the mere description of normal human sentiments to the approval of such sentiments as Nature's provision for human welfare. We ought to follow Nature's guidance, and we make a serious mistake if we try to act against the natural and normal sentiments implanted in us. (Hampshire 1991: 129)
}

Hume follows 'Hume's law' in the sense of stating what "bridge" brings us from 'is' to 'ought' is, namely a naturalistic foundation of morality on welfare, utility and interests. Yet those "smooth transitions" is of course anathema to those philosophers who insist on the alleged naturalistic fallacy. ${ }^{7}$

When realists engage in the debate over fact-sensitivity of normative theory they feature in the latest chapter of this long-standing debate over Hume's law. For instance, when Galston locks horn with G. A. Cohen over the relation between facts and principles, he expresses a typically Humean view. ${ }^{8}$ The principles that Cohen proposes is by Galston regarded as only superficially factindependent, they can appear to be independent only because they rest "on a broad fact about the human species: while we may value happiness, there is a gap between that feature of our species-nature and others, such that we lack some or all of the happiness we crave" (Galston 2010: 405-6). Since Galston seems to think, as noted above, that he is in opposition to Kant and Hume on this score, it is worth pointing out that there is a convincing reading of Hume that instead would make him an ally.

Certainly, "Hume's law" is no cause for questioning the similarity between Hume's philosophical approach and what realists are asking for: a more empirically-informed normative theory. The is/ought passage is in fact "the tailpiece of an extended attack on ethical rationalism" (Raphael 1974: 14). It is therefore a real irony of intellectual history, says Michael Frazer, that Hume has been used to defend abstract normative theorizing detached from empirical facts (Frazer 2010: 174). According to Frazer, the sentimentalist tradition of 
enlightenment thought, of which Hume is a part, as opposed to the more influential rationalist tradition, has as its "greatest potential contribution" to scholarship neither "empirical social science nor normative philosophy alone, but rather a matter of the proper relationship between the two" (Frazer 2010: 175). As realists often express a wish for a re-balancing of this relationship, giving greater weight to empirical facts of politics and human psychology, one way of realizing this vision could well be to turn to Hume, Adam Smith and the sentimentalist tradition of enlightenment thought. ${ }^{9}$ Realists should at least not be blinded to this possibility by Hume's reputation:

Although Hume is widely thought to have insisted on the strict separation of empirical description from normative evaluation, the empirical study of moral and political phenomena is actually central to his normative philosophical project. (Frazer 2010: 7)

\subsection{Motivational realism}

One key difference between realists and moralists is that realists "emphasize the need for psychological and motivational realism" (Galston 2010: 398). They doubt, more specifically, the Kantian and Rawlsian reliance on the reasonableness and good will of citizens. "Reason determines conduct to only a limited degree, and self-interest will always be powerful" (Galston 2010: 398). To be a motivational realist is to focus on actual motivations, and attempt to construct institutions that will work given how humans actually are. The present section will trace similar ideas expressed by David Hume.

Let us begin with Hume's most general remarks on the subject. In the essay "Of Commerce" he famously advises that: "Sovereigns must take mankind as they find them" (Essays: 260). Often quoted is also the proclamation that "all plans of government, which suppose great reformation in the manners of mankind, are plainly imaginary" (Essays: 514). These statements convey realism in the sense that taking people as they are is seen as a condition for good political thinking; it is simply vain to hope to introduce "any violent change in their principles and ways of thinking" (Essays: 260).

But how are people like then? What features and characteristics should we assume when thinking politically? This is spelled out by "the maxim of knavery".

[I]n contriving any system of government, and fixing the several checks and controuls of the constitution, every man ought to be supposed a knave, and to have no other end, in all his actions, than private interest. By this interest we must govern him, and, by means of it, make him, notwithstanding his insatiable avarice and ambition, co-operate to public good. (Essays: 42)

It should be noted that this strong statement is immediately qualified by Hume: it is a political maxim which is "false in fact" (Essays: 261). The maxim doesn't imply a cynical view of human nature, indeed Hume in another essay, "Of the Dignity or Meanness of Human Nature", argues against cynicism, claiming it to 
be pernicious since it may be a self-fulfilling belief (Essays: 81 ; Hume's moderate view of human selfishness also expressed in Treatise: 3.2.2.5). The claim in Hume's maxim is not really that everyone is a knave, but that since politics concern power and wealth, and is a business that involves many people only scarcely acquainted, the stakes will be high while the feelings of honour and shame (which in smaller groups is a "check upon mankind") will have little force over man's behavior (Essays: 43; Whelan 2004: 44). Hence, policies and constitutions should be constructed on the assumption that self-interest will determine behavior and that appeals to public good or rules of justice will often fall upon deaf ears.

The knave maxim offers two interesting connections between Hume and realist theory. First we will look at intellectual history and make note of some connections between Hume and "the realist tradition". Then we will turn to a dispute in contemporary political theory to see the realist impetus of Hume's maxim and how it converges with the criticism formulated by Galston and others.

The first historical connection is the genesis of the idea of pervasive "knavery". This idea is an important similarity between Hume and Machiavelli, indeed Machiavelli is "the most likely candidate for being Hume's direct source" (Whelan 2004: 40). ${ }^{10}$ Of course, Machiavelli is a key figure for contemporary realism, and the key historical reason for placing Hume in the realist tradition is the influence of, and similarities to, the writings of Machiavelli. The knave-maxim and its implications is one of the most direct and immediate connections between the two thinkers.

A second important historical connection is that Hume's maxim on knavery is generally held to have been an inspiration to the authors of the Federalist Papers and the founders of the American Republic. Especially an influence on James Madison's views on how to mitigate the possibly harmful influence of factions, parties and special interests (Whelan 2004: 327). ${ }^{11}$ The authors of the Federalist Papers share Hume's view of human nature as essentially characterized by the pursuit of self-interest and ambition, and hence they see the need for "checks and controuls" which makes ambition counteract ambition in a way that the public good is still promoted despite the actors being inclined to blindly follow selfinterest (2004: 329-30). Though inspired by the classical republican tradition, the federalists diverged crucially on this point. Reliance on public-spirited virtue is the very hallmark of classical republicanism, but the federalists insisted on constructing a system of government that would work even for knaves, i.e. "even in the absence of virtue" (2004: 369). This is a noteworthy historical connection. The Federalists broke from classical republicanism through what seems to be a realist influence from Hume. As Duncan Forbes writes, Hume never agreed with the prevalent view that the ideal republic requires great public virtue in the citizenry (on this score he is even opposed to the legacy of Machiavelli's republicanism), and so he didn't worry about the alleged "corruption" of the citizenry, or joined the calls for a "restoration of manners"; he had "virtually no affinities" to the classical republican "moralists and corruption mongers of his age" (Forbes 1975: 225, 229). ${ }^{12}$ 
Apart from historical connections to past realist thinkers, the knave-maxim has implications for debates in contemporary political theory. To Machiavelli as well as Hume, the "negative" characterization of human nature was primarily in opposition to the preachings of an otherworldly Christian ethics. But as Whelan has argued, the range of ethical ideals to which realists express skepticism is wide: "public-spirited virtue, pure practical rationality (in the Kantian sense), deliberative impartiality in democratic decision-making, the peace-seeking humanitarianism of some modern reformers, and expectations of socialist solidarity and egalitarianism" (Whelan 2004: 292). This doesn't mean that realist disapprove of the values expressed by all these ideals. Realists merely press the point that they are unlikely to be fulfilled except by the devoted, and that it would be foolish and dangerous of us to assume otherwise.

To illustrate this view, let us focus on one of these examples enumerated by Whelan: the ideal of impartial deliberation as decision-procedure. This is a prevalent form of ideal theory in contemporary political theory. The ideals often proposed by theorists of deliberative democracy and advocates of public reason, not least by the major figures of these two approaches, Jurgen Habermas and John Rawls respectively, are by realists held to be naive: realists generally doubts, as Galston says, the extent to which democratic decision-making can be modeled upon a Socratic seminar (Galston 2010: 399; Horton 2010: 433). A proposal dependent on the principle that "everyone is required to take the perspective of everyone else, and thus project herself into the understandings of self and world of all others" (Habermas quoted in Galston 2010: 399), will seem questionable to realists. So when Rawls says we must assume a "certain good faith" in order to deliberate, the retort from Galston is sharp:

\begin{abstract}
But should we assume anything of the sort? Put differently: rather than framing a conception of public reason around the assumption of mutual good faith, perhaps we should go the other way round, shaping deliberative theory and practice in light of the certainty that this presumption will not be equally true for all members of the community. (Galston 2010: 399)
\end{abstract}

It is likely that David Hume would have concurred: the Humean assumption is that "one must work with actual interests and ambitions rather than expecting rational consensus on the public good" (Whelan 2004: 321). In assuming good faith or working from requirements that are unlikely to be fulfilled, Habermas and Rawls breach the knave maxim. The point behind Hume's maxim is that we shouldn't assume good will or sense of fairness, but rather "avarice and ambition". Whatever our wishes to the contrary, there will be knaves. So it is not advisable to propose constitutional arrangements or decision procedures that have been derived on the assumptions that every subject will show good faith. For in thinking on such assumptions you will most likely neglect to consider the means in which knavery and bullying must always be counteracted and contained. Such neglect increases the likelihood that the arrangement will allow bullying to pay off. Being naive about the realization of one's ideals is thus dangerous: "the corruption of the best things produces the worst" (Essays: 73). Better then, according to Hume, to do as Galston advises: start from the fact that some citizens will not show good faith or follow the rules of democratic deliberation, and ask 
the question of what arrangements, given this fact, would maximize the values which we cherish.

Before leaving the topic of motivational realism, I must briefly note that apart from the focus on self-interest, Hume also fits the bill on a second feature of the kind of political psychology that Galston and others demand. Realists not only doubt that reason is as efficacious as to overcome self-interest, they also complain that this "two-tiered psychology of reason and interest" leaves out "an entire dimension of the human psyche - namely, the passions and emotions" (Galston 2010: 398). Simply put, realists would like to rehabilitate the classical trio of motives - reason, interests, and passions - which historically was supplanted by the Kantian view that left no room to the passions. In Hume's philosophy, of course, the passions are in the center, and the power of reason is downplayed. Once again, realists could hardly do better than to turn to Hume and the sentimentalist tradition of the enlightenment if they would like to challenge the Kantian and rationalist legacy on this score.

It should be clear that the topic of motivational realism could be expanded upon $^{13}$, and it may prove to be the most compelling case for realists to draw on Hume. All in all, the realists' emphasis on motivational realism and their calls for political theory to be more focused on institutions as devices for realizing political and social goods in the face of selfishness, partiality, irrationality and wickedness, has a historical precedent in the political thought of Hume:

[Hume's] approach to political philosophy: instrumental, consequentialist, and determined to redirect and channel the dangerous sentiments that we human beings persistently display and act on rather than (as Kantians tend to) trying to reason as if they did not matter. (Sabl 2009: 512) 


\section{Hume as theorist of political order}

\subsection{The critique of contract theory}

In contrast to all the major political philosophers of the modern era, Hume stands out for his criticism of the idea of a social contract as the foundation of government and political order. It may be worthwhile to have a look at his arguments since the contract theories of Hume's time were, as Whelan says, the "most prominent theoretical device of idealist liberalism" of that age (2004: 318). The fact that Hume was its primary critic should be seen as supporting evidence of Hume's realist credentials, and make contemporary realists take an interest in his arguments. Given that realists are opposed to the contractual tradition of grounding legitimacy on the consent, they should bemoan the fact that Hume has been relatively neglected as a political philosopher and that he is not part of the canon in the same degree as contractarian thinkers such as Hobbes, Locke, Rousseau, and Kant.

The social contract was a device used by these thinkers to attempt to answer the central questions of political philosophy: explain the foundations of political order, reason on what the legitimate exercise of political authority is, and explain why and to what degree we have obligations to our government (Lessnoff 1991: $3-4)$. But Hume rejected this way of thinking. His arguments can be found both in the Treatise (3.2.8.3-9) and, more famously, in the essay "Of the Original Contract", in which Hume set out to criticize the two "philosophical or speculative system of principles" that guided the two parties of Great Britain and were used to "protect and cover" those policies which they pursued (Essays: 465). Hume shows little patience with the philosophical doctrine of the Tories, perhaps even being, according to Rawls, "somewhat deliberately insulting" (Rawls 2007: 165). The Tory doctrine of "tracing up government to the DEITY" has the untenable consequence of rendering authority "so sacred and inviolate, that it must be little less than sacrilege, however tyrannical it may become, to touch or invade it, in the smallest article" (Essays: 465). But the prime target was the Whig doctrine of a contract, and generally of "founding government altogether on the consent of the PEOPLE" (Essays: 466). ${ }^{14}$

Hume's critique begins with a look at the facts. "[W]ould these reasoners look abroad into the world", he says, they would find nothing to support their system: everywhere there are rulers who demand obedience of their subjects with little regard to their consent; obedience is commanded on basis of conquest or succession (Essays: 469-70). It is unlikely, Hume thinks, that present rulers are simply usurpers of a previous contract that established the political authority; more likely, the political rule was originally established by the use of force and conquest. Moreover, the present rulers' claims are commonly accepted: the subjects tend to "acknowledge this right in their prince", and find that they are 
"born under obligations of obedience" to a certain rule, just as they are born to give respect to certain parents (Essays: 470; the argument is also found in Treatise: 3.2.8.8-9). People in general do not inquiry into the origins of the rule to which they are subjects, and if they do, they would not fancy that its origins lay in a contract and consent. Only "philosophers" could come up with an idea so remote from the experiences of mankind.

\begin{abstract}
Were you to preach, in most parts of the world, that political connexions are founded altogether on voluntary consent or a mutual promise, the magistrate would soon imprison you, as seditious, for loosening the ties of obedience; if your friends did not before shut you up as delirious, for advancing such absurdities. It is strange, that an act of the mind, which every individual is supposed to have formed, and after he came to the use of reason too, otherwise it could have no authority; that this act, I say, should be so much unknown to all of them, that, over the face of the whole earth, there scarcely remain any traces or memory of it. (Essays: 470)
\end{abstract}

If the contract is supposed to be so ancient as to have been naturally forgotten, then the retort is to ask how such a contract could now be regarded as having any authority (Essays: 471). The philosopher can make the move, as John Locke did, of saying that by living under a particular rule one has given tacit consent to its authority. But consent must in any event depend on the existence of a choice. And chosen we have not: first of all because most of us are born into the society in which we live our lives, and secondly because we commonly lack the effective means and opportunity to move and settle in another country.

Can we seriously say, that a poor peasant or artizan has a free choice to leave
his country, when he knows no foreign language or manners, and lives from
day to day, by the small wages which he acquires? We may as well assert,
that a man, by remaining in a vessel, freely consents to the dominion of the
master; though he was carried on board while asleep, and must leap into the
ocean, and perish, the moment he leaves her. (Essays: 475)

The argument is that mere residence is so to speak "insufficiently voluntary" in order to ground obligations and legitimacy (Horton 1992: 34). No matter how you twist and turn the concepts of contract and consent, they can never be made credible as explanations of political order or as reasons for our obligations to that order. ${ }^{15}$ Consent is simply not part of the story:

[W] ere all men possessed of so perfect an understanding, as always to know their own interests, no form of government had ever been submitted to, but what was established on consent, and was fully canvassed by every member of the society: But this state of perfection is likewise much superior to human nature. Reason, history, and experience shew us, that all political societies have had an origin much less accurate and regular; and were one to choose a period of time, when the people's consent was the least regarded in public transactions, it would be precisely on the establishment of a new government. (Essays: 474) ${ }^{16}$

The general problem with the contractual account is that its sets too severe demands for legitimacy. If mutual agreement is the source of the legitimacy of the political order, then if the facts of the matter are that, as Hume puts it, "the original establishment was formed by violence, and submitted to from necessity", 
and that the rest of political history contains nothing "but force and violence" (Essays: 475, 471), then there is only one conclusion to be drawn: all present authority is illegitimate, the bonds of obligation are broken. Hume of course finds that conclusion unpalatable. Hume's critique was directed Locke's assertion that "absolute monarchy ... can be no form of civil government at all" (Locke 2002: 40), a conclusion which Hume viewed as in itself a good reductio ad absurdum argument against such contract theories (Essays: 486-87; Treatise: 3.2.8.9; Forbes 1975: 141-42, 153). As he writes in the Treatise, just because we cannot account for the allegiance to a ruler in a way that satisfy any "reciev'd system of ethics", we cannot believe ourselves to be exempt from the duty of allegiance (Treatise: 3.2.10.7). Few governments would pass the test if "examin'd so rigorously", and we would have to conclude "that all the known world, for so many ages, had no government, and ow'd no allegiance to any one" (Treatise: 3.2 .10 .7 ).

All in all, the critique of the contract theory makes Hume a man for the realists. An important part of the tradition which they criticize is the contractarian legacy, especially the Kantian version which was revived by John Rawls. Just like Hume, contemporary realists claim that much of liberal political theory set unreasonable conditions for legitimacy:

[At] the end of the day, coordination will require coercion or the threat of coercion. This does not mean that we cannot distinguish between legitimate and illegitimate terms of coordination, only that the presence of coercion is not a sufficient condition of illegitimacy. (Galston 2010: 390)

Surely, a realist would bemoan that the essay "Of the original Contract" did not achieve the impact which Russell Hardin has argued it deserved: "This astonishingly smart essay, which is short and acute, should have put an end to contractarian political thought" (Hardin 2007: 120).

But it had some influence, though it was not for the good. Hume's essay was an attack on the abstract thought of "reasoners" who proposed their philosophical principles without an eye to the empirical facts and historical record. But his critique came to influence Kant to make the contract theory wholly immune to empirical facts (Riley 1973: 451). ${ }^{17}$ Hobbes and Locke had distanced themselves from earlier contract theories by rejecting the notion, prevalent at the time, that the contract was continually renewed with every succession of rulers; they so to speak pushed the contract back in time (Lessnoff 1990: 12). ${ }^{18}$ But then two questions were naturally raised: did such a contractual founding ever take place, and if so, would such a contract really have binding force for those living now? ${ }^{19}$ It was on both these issues that Hume rejected the contractarian arguments. But in response, Kant was led to devise a purely hypothetical contract, and he thus became the first contract theorist to explicitly deny the historicity of the contract (Lessnoff 1990: 13-14). The point was to consider which terms would have been consented to at a hypothetical founding of political society. Each law must pass this test: it should be possible for everyone to have consented to it. The test is thus the standard for what should count as legitimate political authority (Peter 2010; Kant 1991: 79). 
We can confidently say that Hume would not have accepted Kant's strategy. Kant makes the contract an "Idea of Reason", which in his philosophy means that it is an idea impervious to empirical claims; it cannot be proved or disproved by empirical investigation (Kant 1991: 79, 83, 143; Reiss 1991: 27-28). Hume would have disapproved. For Kant's move here would give a carte blanche to the "reasoners" whom Hume repeatedly mocked. Indeed, it gave such a carte blanche, and the result - the abstract contractarianism, evident in Rawls' theory of justice as well as other accounts of liberal legitimacy - is an important part of the moralism which realists are today criticizing. Of course, we cannot know in detail what Hume would have thought of Kant's reformulation of the contract theory. But a good guess, I think, would be that he would have agreed with those who have argued that Kant's theory is a consent theory "in which the idea of consent does no work at all" (Miller \& Dagger 2003: 453). The problem when there is no appeal to actual consent but only to what people would freely consent to if reasonable, is that such a procedure to judge the legitimacy of a political regime becomes solely a matter of what the author deems reasonable. The move to a hypothetical consent makes the theory refer to the qualities and features of the state, contemplating what regime is worthy of our consent (Wolff 2006: 44). This may seem a mere theoretical shift, but it does have implications for how to conduct political theory. Specifically, it has what I call the carte blanche consequence, here described by John Horton:

\begin{abstract}
A further feature of this transition which should be noticed is the enhanced role of the theorist of political obligation. Within voluntarist theories, there is an irreducible role for agents in the real world: it is they who do or do not consent. [...] However, within hypothetical consent theories there is no role for agents in the real world. Their 'choices' are modelled and determined by the political philosopher or theorist; it is the theorist's arguments which establish the validity of 'consent' and not the actions of agents in the real world. Hence there is no need to look to the histories and actions of actual people, instead it is the theoretical arguments of the philosopher which are crucial. (Horton 1992: 83)
\end{abstract}

But at this point one may of course start to wonder whether the hypothetical contract is really a contract theory at all. The central concept of consent "simply drops out of the picture" (Wolff 2006: 45). John Horton makes the same point (Horton 1992: 82-83), adding that it is unfortunate that the move to hypothetical consent should count as a "reinterpretation", when in fact it stands the contract theory on its head: it does not ground obligation on consent, but state the conditions for when consent is rationally obligated (1992: 84-85). However, the "reinterpretation"-view is not surprising, since "confusion between the logic of voluntarist theories and 'hypothetical consent' is deeply enshrined within the social contract tradition" (Horton 1992: 85). Russell Hardin, as quoted above, lamented the fact that Hume's critique did not put an end to contractarian thought. But we can now ask, perhaps it actually did? ${ }^{20}$ 


\subsection{Human sociality and the origins of government}

The previous section on Hume's critique of social contract theory raise a host of questions regarding what Hume's positive alternative is. In what sense and on what ground do Hume think we have political obligations, granted we have not consented to the authority? How did political rule and governments really emerge, granted that it was not created by a group coming together to institute it or to select a leader? These are big questions, but as space is brief we must continue to let the concerns of contemporary realists set the direction for the present investigation of Hume's thought. On that ground I will choose to expand on Hume's descriptive account of humans as social beings and of the origins of political authority. His view, I will argue, has some important similarities to one of the features that Galston has singled out as distinctive to realists.

One important problem facing realists is that they must supply an account of social and political life that makes plausible their contention that politics is a distinctive sphere of human activity. For that is the basis for their claim that apolitical ethical theories are inapplicable to politics and political behavior. In short, they need an account of politics which makes "the ethics-first view" void, and which gives grounds for the possibility of a normative political theory that still "cannot be derived from non-political morality" (Galston 2009: 88). Galston admits that this question has been somewhat neglected, but his own brief suggestion, mentioned above in chapter 2 , builds on previous efforts and provide a fuller account (2010: 390). It is the view that human nature is characterized by unscripted sociality.

Aristotle offers a useful point of departure. Humans are social animals, but
unlike other social animals (bees or ants) the terms of social coordination are
not hard-wired. The basic structure of political life is thus unscripted
sociality; while we cannot escape the necessity of coordination, its terms
somehow must be constructed and made effective. (Galston 2010: 390)

We can unpack this notion into two parts. Natural sociality on the one hand, and on the other its "unscriptedness" and the subsequent need for deciding on, and then upholding, certain terms of coordination and cooperation. This, I would say, is what we also find in Hume.

To show this I will now briefly set out Hume's empirical views on political order and how it emerges. I think this can usefully be done while drawing on Francis Fukuyama's recent book The Origins of Political Order (2011), a book which covers what modern science teaches about these issues, often in contrast to the theories of many of the major political philosophers. This allows me to show the similarity between Hume's views and those of modern social science, as well as the differences to Hobbes and Locke. At the same time, though of less importance, we also get so see an example of how political science typically has neglected Hume. Tellingly, Fukuyama laments the loss of wisdom constituted by the early modern philosophers supplanting Aristotle's view of the political nature of man with state of nature theories in which the individual somehow pre-dates the birth of society (2011: 26). 
[Rousseau], Hobbes, and Locke were wrong on one very important point. All three thinkers saw human beings in the state of nature as isolated individuals, for whom society was not natural. According to Hobbes, early human beings relate to one another primarily through fear, envy, and conflict. Rousseau's primitive human is more isolated: while sex is natural, the family is not. (Fukuyama 2011: 29)

This "Hobbesian fallacy" Fukuyama contrasts with "what we actually know today about human origins", by consulting anthropologists and evolutionary biologists. What we know is of course that, within kin, the opposite is the case. Hence Aristotle was "more correct than these early modern liberal theorists" (2011: 29). True enough, but so too was another thinker of that very age and inclination: "Man, born in a family, is compelled to maintain society, from necessity, from natural inclination, and from habit. The same creature, in his farther progress, is engaged to establish political society" (Essays: 37). Within a few pages Hume proclaim man's natural sociability, while at the same time identifies the main problem of social order in that large scale social interactions create Prisoner's dilemmas and opportunities for free-riding. ${ }^{21}$ Thus he describes the need for, and problem of, creating political institutions. Now this is exactly what Fukuyama's book is about, and my hunch is that if Hume had been properly a part of the canon of political science then Fukuyama wouldn't have missed the opportunity of providing a fruitful discussion of Hume's thought in connection to the findings of modern social science.

Like Hobbes, Hume says that violence and the need for security is what drives the development towards the institutionalization of political authority. But there is one crucial difference.

And so far am I from thinking with some philosophers, that men are utterly incapable of society without government, that I assert the first rudiments of government to arise from quarrels, not among men of the same society, but among those of different societies. ${ }^{22}$ (Treatise: 3.2 .8 .1 )

In contrast to Hobbes, Hume even says that a "society without government is one of the most natural states of men" (Treatise: 3.2.8.2). The "Hobbesian fallacy" was evidently not committed by all early modern liberal thinkers; rather, what we learn from modern science about the early forms of social life actually seems to corroborate the views of David Hume, Adam Smith and other figures of the Scottish enlightenment. ${ }^{23}$

However, one may also argue that Fukuyama's account of the Hobbesian fallacy is uncharitable to the social contract thinkers. To think that they meant that everyone was truly "on his own" before the social contract, is to misunderstand what the contract was about. Despite the name, it is not "society" that is so established, but political society (or 'civil' society as these thinkers called it). Hence it could be said that Fukuyama (and Hume) partly argues against a straw man; the state of nature was even to the contract theorists actually a social condition (Lessnoff 1990: 2-3; Forbes 1975: 72).

But even granted this, there remains an important difference between these thinkers and Hume. For Hume maintains not only that individuals are always social creatures and living in families, but that a large group of families living 
together, a tribe, is a genuine and sustainable form of social organization, they subsist "long after the first generation" (Treatise: 3.2.8.2). In contrast, in Locke's writings the state of nature seems "so uncomfortable and so short-lived as to appear more like an argument for government than a possible human state" (Forbes 1975: 73). In that sense the extent of the sociality of human nature is still a distinguishing feature of Hume's thinking.

We turn now to the "unscripted" part of the story (no pun intended). The fullest statement of the idea of unscripted sociality is that of Raymond Geuss:

\begin{abstract}
Although $[\ldots]$ it seems a natural and not an artificial fact about humans as we know them $[\ldots]$ that we are in this sense social and not solitary creatures, it is also the case that in modern societies human interaction is not something that can ever be taken for granted [...]. The members of a human group are not parts of a single organism, like the hands or feet of an animal, who have no will of their own, nor are we like bees, ants, or even herd animals whose strong natural instincts can be counted on, at least in some areas, to be powerful enough to assure more or less harmonious coordination. Rather, humans, even in the most repressive societies we know, grow up to be individuated creatures who are separate centres for the formation, evaluation, and revision of beliefs, attitudes, values, and desires, and for the initiation of action that puts these beliefs and desires into effect. So coordination of action in our societies, either of a negative kind (that I don't act so as to thwart your plans) or of a positive kind (that I act so as to maximize the attainment of some goal that can be reached only by joint effort) is always a social achievement, and it is something attained and preserved, and generally achieved only at a certain price. (Geuss 2008: 21-22)
\end{abstract}

I take this to mean that, for better or worse, if the social instincts of humans had been stronger, politics and government would have been redundant phenomena. Had humans been like ants, like in Geuss example, no parliaments or town halls had ever been built; there wouldn't exist a need for such a thing as "politics" among such creatures.

That line of thought is reminiscent of the reasons Hume gives for why mankind eventually leaves that pre-political social state. Hume offers a coordination theory of the origins of the state (Hardin 2007: 105, 118). To understand this, we must first realize why Hume, in contrast to Hobbes and Locke, regarded a pre-political form of society as wholly functional (though primitive). What Hume understood, but Hobbes did not, was that small scale societies could achieve coordination through social mechanisms other than the use of political power (Hardin 2007: 107, 111, 135). Most likely this was because in Hume's time knowledge of the tribal societies of North America was more readily available (Hardin 2007: 113, 223; Whelan 2009: 7,9). In a society in which everyone know each other, conventions that ensue coordination and cooperation can be upheld without the institution of a sovereign. This is because everyone's behavior is monitored by everyone else: violations of such conventions can then be "punished" through the group turning their back toward the "defector". Hence in small-scale societies people are generally reliable in their dealings with each other; social order obtains even without "the heavy machinery of government" (Hardin 2007: 111; Treatise: 3.2.2.24). In a hunter-gatherer society, like the North American societies which Hume reflected upon, there are few possessions (and thus few reasons for transgressing the rules of justice), and more 
importantly, the transgressions that still occur will be immediately known to everyone in the society (Treatise: 3.2.8.1; Hardin 2007: 112).

However, it is a very different story in large-scale societies: "the force of this sanction is almost nil if we are in a large society in which I can readily find others with whom to cooperate" (Hardin 2007: 135-36; Stewart 1963: 150-51). In large societies there are opportunities to sidestep the rules and conventions that are necessary for social peace and prosperity, gratifying one's own interest without necessarily suffering any cost. It is under such circumstances that the Hobbesian egoism of humans will make itself known and override the conventions of justice and property.

\begin{abstract}
All men are sensible of the necessity of justice to maintain peace and order; and all men are sensible of the necessity of peace and order for the maintenance of society. Yet, notwithstanding this strong and obvious necessity, such is the frailty or perverseness of our nature! it is impossible to keep men, faithfully and unerringly, in the paths of justice. Some extraordinary circumstances may happen, in which a man finds his interests to be more promoted by fraud or rapine, than hurt by the breach which his injustice makes in the social union. But much more frequently, he is seduced from his great and important, but distant interests, by the allurement of present, though often very frivolous temptations. This great weakness is incurable in human nature. Men must, therefore, endeavour to palliate what they cannot cure. They must institute some persons, under the appellation of magistrates, whose peculiar office it is, to point out the decrees of equity, to punish transgressors, to correct fraud and violence, and to oblige men, however reluctant, to consult their own real and permanent interests. (Essays: 37-38)
\end{abstract}

In short, humans are social beings dependent on each other, and able to set up conventions of "justice" that allow for peace and coordination; yet there are limits to their instincts and abilities in this regard, and people are tempted into breaking the conventions by the prospect of satisfying individual and immediate interests. This is reminiscent of Galston's description of the realists' view: coordination is "necessary" for humans, yet her social instincts are not strong enough to guarantee that it occurs, and thus the need for the terms of coordination to be "constructed and made effective" (Galston 2010: 390). That last step, presumably, is why politics can be seen as a distinctive sphere of human activity. Politics would be redundant given stronger instincts to cooperation. We can find the same line of thought in Hume: if our propensity to follow the rules of justice had been stronger there would be no need to "have governments to enforce compliance with the principles" (Hardin 2007: 114). Or as Hume himself puts it:

Had every man sufficient sagacity to perceive, at all times, the strong interest, which binds him to the observance of justice and equity, and strength of mind sufficient to persevere in a steady adherence to a general and a distant interest, in opposition to the allurements of present pleasure and advantage; there had never, in that case, been any such thing as government or political society, but each man following his natural liberty, had lived in entire peace and harmony with all others. What need of positive law, where natural justice is, of itself, a sufficient restraint? EPM: 4.1 


\section{Realist liberalism: the balancing act}

So far in this paper I have traced and depicted several features of David Hume's thought which show a similarity to the ideas and ways of thinking that realist political theorists seek to advance today. The result, I would like to think, is that Hume should be joined to Hobbes and Machiavelli in the category of important realist thinkers.

But why would that be important? That is, does Hume's realism offer something distinct of its own, not simply showing a great Machiavellian influence, or evidence for thinking that he is, with Brian Barry's words, a "closet Hobbesian" (Barry 1989: 148)? In short, does he offer something that realists could not already find in Machiavelli or Hobbes?

One answer would be that Hume's thought might offer some help in a difficulty that many realists encounter when they are simply playing their Hobbes or Machiavelli to the moralists' Kant. Many realists are apprehensive of going "too far": while they are looking to correct the idealistic features of much liberal theory, they do not wish to throw liberalism overboard. The difficulty is expressed by Richard North as the attempt to steer a middle course between moralistic liberalism on the one hand and accounts of politics that "sit rather too comfortably with Machiavelli and Hobbes" on the other (North 2010: 384). With this in mind Hume's realism becomes more significant. For in contrast to those two thinkers, Hume is also a classical liberal. ${ }^{24}$ That combination of liberalism and realism gives us reason to think that Hume may hold some clues for such realists as Galston, who are looking to forge a more robust liberalism.

\footnotetext{
The characteristic vice of liberalism is a shallow optimism, the belief that economic and social contrivances can eliminate, or permanently override, the darker aspects of our nature. A deeper and more sustainable liberalism must construct its domestic institutions and conduct its foreign relations with these harsher realities firmly in view. Liberal orders that do not understand this will be startled, perhaps overwhelmed, by new forms of antiliberalism. (Galston 2009: 92-93)
}

This chapter will discuss this balancing act between liberalism and realism. My suggestion is that a stimulating example of such balancing occurs in Hume's writings. Indeed, I think that it is the attempt at such balancing that explains the long and apparently insoluble controversy over whether Hume is a Tory or a Whig, a dispute which has continued ever since the publication of the first volume of Hume's The History of England. My suggestion is that an examination of that work could be illuminating for liberal realists concerned with "steering a middle course" and who are in need of principles for making judgments between liberal ideals and the necessary means for maintaining political order.

This suggestion builds on Frederick Whelan's study, which has the broader purpose of delineating a realist form of liberalism (Whelan 2004: ix, 1, 290). Hume is usually and rightfully regarded as a liberal thinker, and so Whelan's 
study, by highlighting the realist side of Hume, casts him as a founding figure of "realist liberalism", contrasted with idealistic versions of liberalism represented by Locke and Kant and their modern heirs Rawls and Habermas (Whelan 2004: 290, 315, 325). That form of liberalism is a "robust hybrid": liberalism supplies the normative dimension and the values to be pursued, while the realist element makes the theorist always consider means and practical possibilities, keeping expectations "within reasonable bounds" (Whelan 2004: 317).

The realist element of this combination, in Hume as well as in contemporary theorists, is first of all the high valuation of political order and a sense of its frailty. At the most general level, contemporary realists are at odds with Rawls' view that justice "is the first virtue of institutions" (Rawls 2005: 3). Bernard Williams and other realists instead hold that "the first virtue of politics is order, not justice, and justice purchased at the expense of order is likely to prove selfdefeating" (Galston 2010: 388). But this leads to the difficulty of combining this with a commitment to liberal progress. If order is the first virtue, how are we to square this with the potentially unsettling effects that liberal reforms in many circumstances entail? This is what I see as the central issue regarding the possibility of a realist liberalism. While realists question liberalism's traditional account of legitimacy and emphasize the need for order, the danger is that their critique will do away with all reasons for dismay at the, arguably "necessary", use of coercive or illiberal measures and means. Relatedly, we also have the thorny issue of how one is to face the fact that most regimes do not satisfy the liberal ideals or requirements of consensus and agreement. These two questions both concern the issue of combining realism with a commitment to liberal progress.

When we consider that liberalism, the rule of law, and individual rights are recent historical phenomena, we must either conclude that earlier regimes were illegitimate, or else, devise a theory which allows that non-liberal regimes can be or have been legitimate. The first of these alternatives is often tacitly chosen in much "moralistic" liberal theory, which according to Bernard Williams "has a universalistic tendency which encourages it to inform past societies of their failings" (Williams 2005: 10). Realists like Williams instead hold that we must acknowledge that there have been past societies that have been non-liberal but legitimate political orders (2005: 8-11). The historical circumstances decide the relevant conditions of legitimacy. But here comes the balancing act. Those liberals who allow that there have been non-liberal legitimate political orders must face crucial questions regarding how one is to make historical judgments concerning the possibility and price for liberal progress. When and on what grounds are those possibly disruptive measures that historically have yielded liberal-democratic regimes legitimate. Perhaps, when we do not hold non-liberal societies to the same standards of legitimacy as our contemporary liberal-democracies, we may have deprived ourselves of the normative resources necessary to support changes in those societies? The emphasis on order may overrun our liberal aims, since the means to achieve these aims may be de-stabilizing. Such an excessive valuation of stability would be one way in which realists risk ending up sitting too comfortably with Machiavelli and Hobbes. For instance, even though Bernard Williams is more hopeful of political progress and ambitions than Geuss, both have been 
accused, even by sympathetic critics "above all to prioritise stability as a political good" and thus of neglecting "the issue of how much evil is tolerated or ignored because of fear of instability" (Honig \& Stears 2011: 191, 194).

My suggestion is not that Hume solves these issues, only that his struggle to do so merits the realists's attention. Similar lines of critique have been levied against both Hume and contemporary realists, namely that of excessive pessimism: that the emphasis on order make them in practice conservative despite their liberal claims and ambitions.

To set up the discussion of Hume's balancing act, let us consider a very general transformation of western political thought. Pasquale Pasquino writes:

\begin{abstract}
Political theory is about order inside the city. I suggest that it is more precisely the series of texts on the means of avoiding disorder which threatens coexistence within the political community. [...] [T] ransformations of political discourse in the West have been a function of changing conceptualizations of threat to the existence of political order and hence of the different ways of envisaging the origin and nature of this threat. (Pasquino 1996: 19)
\end{abstract}

What is that change? Liberal theory is driven by the threat of abuse of power, the risk that public officials step out of bounds in their use of coercive measures and thus threaten the life and liberty of the subjects. This liberal line of thought, as Pasquino writes, "is so much part of our intellectual horizon that it is easy to forget that it was not always like that" (Pasquino 1996: 20). In earlier theorists, most obvious in the case of Hobbes, "one notices the almost total absence of the 'liberal preoccupation' with the limitation of state power" (1996: 20-21). The threat that drives Hobbes' theory is the evil of disorder. Contra liberal theorists, the state then appears not as the major threat but as the savior and guardian against the other and more basic threat. The state creates order and security, and Hobbes' Sovereign will then be seen as "the precondition of the liberty of his subjects, rather than a source of danger and threat" (Pasquino 1996: 21).

When modern states had developed, the threat of disorder receded from view, and the "liberal preoccupation" came to define the relevant threat. However, Hume was still concerned with this question, and perhaps we should say that his thought has a peculiar relation to this transformation of the conceptualization of threat: it is unusual in its attention to both concerns. Later liberals - Russell Hardin singles out Mill and Rawls as contrasts to Hume - take for granted what earlier theorist saw as "the central issue to be understood: social order" (Hardin 2007: 210). In contrast to these later liberals, Hume is elaborating a basically Hobbesian political theory. According to Hardin the similarity between Hobbes and Hume is both remarkable and yet also "remarkably overlooked" in the literature: "Hume's theory of politics seems to have more in common with that of Hobbes than with any other" (Hardin 2007: 223). It is certainly not difficult to find in Hume's writings the Hobbesian conception of threat and the corresponding view that the order that the state can impose is a precondition for liberty. One example can be found in the first volume of the History of England:

[T] he civil union being weak, many private engagements were contracted, in order to supply its place, and to procure men that safety, which the laws and 
their own innocence were not alone able to insure to them. On the whole, notwithstanding the seeming liberty or rather licentiousness of the AngloSaxons, the great body even of the free citizens, in those ages, really enjoyed much less true liberty, than where the execution of the laws is the most severe, and where subjects are reduced to the strictest subordination and dependance on the civil magistrate. The reason is derived from the excess itself of that liberty. Men must guard themselves at any price against insults and injuries; and where they receive not protection from the laws and magistrate, they will seek it by submission to superiors, and by herding in some private confederacy, which acts under the direction of a powerful leader. And thus all anarchy is the immediate cause of tyranny, if not over the state, at least over many of the individuals. (History I: 168-69)

It is to this Hobbesian foundation that Hume adds his liberal ideals and aspirations. The resulting combination ensures that for Hume it will always be a difficult matter to judge which balance between authority and liberty is the appropriate. However, Hume does express a general view of how these values relate to each other. This comes up when in the last volume of the History Hume offers his verdict on the Whigs. While the party's rule has brought about progress, its propagandists have obscured the truth about political history, and most importantly, misunderstood the relation between liberty and authority:

[T] hese events have long, by the representations of faction, been extremely clouded and obscured. No man has yet arisen, who has payed an entire regard to truth, and has dared to expose her, without covering or disguise, to the eyes of the prejudiced public. Even that party amongst us, which boasts of the highest regard to liberty, has not possessed sufficient liberty of thought in this particular; nor has been able to decide impartially of their own merit, compared with that of their antagonists. [...] [F]orgetting that a regard to liberty, though a laudable passion, ought commonly to be subordinate to a reverence for established government, the prevailing faction has celebrated only the partizans of the former, who pursued as their object the perfection of civil society, and has extolled them at the expence of their antagonists, who maintained those maxims, that are essential to its very existence. (History VI: 532-33)

In short, order is the first virtue of institutions, and liberty is the perfection of the political society. That is the principle that guided Hume in his ambitions in the History to make fair historical judgments on policies and rulers, and on issues of revolution and constitutional reforms. ${ }^{25}$ These two quotes taken together express the view that the fullest liberty is achieved by a balance between authority and liberty; such a balance is the only way for the citizens to be able to conduct their lives free from fear, because the fear comes from two threats: from the disorder among ones fellows, and from the abuse of power by the officials entrusted to deal with and overcome that disorder.

This double perspective naturally leads one to be cautious in one's judgments on the measures taken by regimes and rulers in vastly different historical circumstances. As is evident in Hume's essays and historical writings, he is reluctant to blame past regimes and political actors for "not practicing policies (toleration, but also press freedom and habeas corpus) that seem dangerous in prospect and prove viable only in retrospect" (Sabl 2009: 515; a fuller treatment of the three cases is given in Sabl 2002: 79-81). Hume never forgets the Hobbesian threat, or allows himself to hold past societies to standards that their 
less fortunate circumstances would not allow them to fulfill. The example of habeas corpus is instructive. Hume express great sympathy for this set of laws, saying that since such laws at this time (the reign of Charles II) seemed to exist only in England, that fact alone "may induce us to prefer our present constitution to all others" (History VI: 367). But characteristically he goes on to say:

\begin{abstract}
It must, however, be confessed, that there is some difficulty to reconcile with such extreme liberty the full security and the regular police of a state, especially the police of great cities. It may also be doubted, whether the low state of the public revenue in this period, and of the military power, did not still render some discretionary authority in the crown necessary to the support of government. (History VI: 367)
\end{abstract}

So judgments of the advisability of progressive revolt and reform are for Hume highly dependent on the historical context. And that is why it might be highly relevant to contemporary liberal realists to study how Hume struggles with making such judgments. The issue concerns how to square ones political ideals and philosophical doctrines with what the historical situation allows, square it with a clear-sighted view of what the likely results are of acting on and implementing those principles. Indeed, the solution to the question of whether Hume is a Tory or Whig, and the meaning of his claims to impartiality, might simply be that he is changing sides according to what he takes the circumstances to allow: "he is always partial, even if he is not always on the same side" (Wootton 1993: 301). To this simple explanation we can add Hume's own famous self-description: "My view of things are more conformable to Whig principles; my representations of persons to Tory prejudices" (Letters I: 237). This short remark harbors a view that, I would say, could be one for realists to develop. For their rejection of the "ethics-first view" means that they are on the search for a way of judging policies and political actors that is more sophisticated than the Kantian "bend its knee before the right"-manner. ${ }^{26}$ And thus they may find it tempting to follow Hume, as he once again diverges from the established views in political theory:

This opposition between Hume's assessment of persons and his assessment of principles is striking. In Hume's time as well as ours, all common systems of political ethics take it as an axiom that good character and action according to proper principles go together: whether the former is a shorthand for a tendency to the latter, as in Kant, or the latter is derived from the existence of the former, as in Aristotle. (Sabl 2002: 74) 


\section{Conclusion}

The aim of the paper has been to show that many of the contemporary realists' central ideas can be found in the thought of Hume. It was the lack of attention to Hume in the writings of contemporary realists that was the prime motive for writing this paper. ${ }^{27}$ My claim is that realists could fruitfully build or draw upon those features of Hume in their attempts to develop the kind of political theorizing that they would like to see rival the dominant Kantian variety. I will now restate the most important reasons for why a Humean mode of political theory would be attractive to realists.

One important characteristic is that Hume is a philosopher of the non-ideal kind. Like realists today, Hume was dissatisfied with the abstract arguments of "reasoners" who decided right from wrong through invoking some abstract moral system, undisturbed by the practical realities and limitations of humans and their societies - and by the moral complexity that any clear-sighted account of human life must acknowledge. On the most general level, this comes out in Hume's entire approach to philosophy. Despite what "Hume's law" is usually taken to mean, Hume's thought is characterized by the very opposite of the Kantian principle of making normative reasoning wholly independent on empirical features of the world, a principle which realists such as Geuss and Williams have spent much effort to criticize.

At a level of lesser generality, we can see this non-ideal approach in Hume when he advises that policies and constitutions should be devised on assumptions that take into account the actual motivations behind people's behavior. Though fundamentally an empirical question, the safest assumption to be made is that selfinterest will often guide behavior to a significant degree. This motivational realism leads to a focus on institutions as vehicles to achieve coordination in spite of selfishness, bias, and irrationality.

The non-ideal character also shines through when we turn to Hume as a theorist of political order. Like realists today, Hume was critical of the habit of setting legitimacy conditions which, even though expressing a valid ideal, would have as a consequence that almost every established rule in history would have been illegitimate. Instead, we must face the fact that the story of the origins of government is not a morally uplifting tale that satisfies the political ideals that we today hold dear. Founding political obligation on a supposed contract was the main variety of idealist liberalism in Hume's time. The fact that Hume was alone as a major thinker to reject this way of thinking speaks for his realism. But it should be acknowledged that contemporary realists might not stand more to gain than the recognition of intellectual affinity. For the contractarian thinking that they oppose today are of a Kantian kind (through Rawls' influence), a variety which was developed after Hume's death and with the explicit intention to be made immune to the sort of criticism that Hume had levied against earlier contract theories. 
With regard to Hume's own account of the origins of government a fourth important similarity appears. Hume's account included a view of human nature that shares some important features with what realists such as Galston and Geuss have described as the grounds for the realists' insistence on viewing politics as a distinctive sphere of human activity. The "unscripted sociality" that these thinkers describe could be found in Hume. In contrast to most of the contract thinkers, Hume lays a greater stress on the natural sociality of mankind. Yet when human societies grow, the social and moral instincts are not strong enough to ensure coordination and cooperation. Hence the need for government: it is demanded by the "unscriptedness" of human sociality, which requires that the terms of social cooperation are deliberately "constructed and made effective" (Galston 2010: 390).

Lastly, since Hume combined his realism with a commitment to liberalism, he would be of interest to those realists whose critique of moralistic liberal theory is not intended to reject liberalism as a whole. Hume and contemporary realists share the Hobbesian starting point in stressing the need for security and order. But a liberal, of course, cannot hold what Hobbes did: that the need for order overrides all other concerns and alone set the conditions for political legitimacy. Since Hume rejects that Hobbesian conclusion, and his work instead is characterized by the attempt to find the proper balance between order and liberty in different historical settings. For that reason Hume's thought is potentially more interesting than Hobbes' to those realists hoping to develop a realist liberalism.

Since all of these themes concern large questions suitable for book-length studies, it should be acknowledged that the treatment in this paper has been summary. Yet that brevity was required to achieve the purpose of showing the potential that Hume's thought has for realists looking to develop a comprehensive alternative to Kantian and other ideal forms of political theory. 


\section{Notes}

${ }^{1}$ Apart from the three theorists already mentioned - and whom will feature predominantly in the present paper - the following authors are often seen as being part of the same movement: John Dunn, Richard Bellamy, Glen Newey, John Gray, Geoffrey Hawthorn, Mark Philp, John Horton, Jeremy Waldron, and Judith Shklar.

2 One problem with this term though is that it is used in many other contexts. The "realism" described in this paper is distinct from the realist school in the field of international relations, as well as from realism as philosophical position on questions regarding the meta-ethical status of different claims.

${ }^{3}$ I will use the following abbreviations to refer to Hume's writings: 'Treatise: [page nr]' refer to $A$ Treatise of Human Nature (2007); 'Essays' to Essays: Moral, Political, and Literary (1987); 'EPM' to An Enquiry Concerning the Principles of Morals (1998); 'History I' to The History of England. Volume I (1983a); 'History VI' to The History of England. Volume VI (1983b); 'Letters I' to The Letters of David Hume Volume I: 1727-1765 (2011).

${ }^{4}$ It should be noted that I still have made some exclusions. I have concentrated on the themes of greatest theoretical importance, which means that I do not discuss the similarities of lesser generality. For instance the realist affinities between Hume and Machiavelli when it comes to statecraft and foreign policy - issues such as secrecy, deception, power politics, reasons of state are not covered even though this familiar sense of "realism" is also part of the movement depicted by Galston.

${ }^{5}$ For an overview of Guess' realism, see Rossi 2010.

6 An overview of Williams' political thought is given in Sleat (2007). The successfulness of Williams' attempt to develop a "realist liberalism" is questioned in Sleat (2010).

${ }^{7}$ There are two historical notes to make here. Hume's views show similarity both backwards to an ancient view, perhaps most clearly in the case of Aristotle, and one forward connection to evolutionary ethics inspired by Darwin. The backward connection is to Aristotle and others who "founded ethics on the appetitive nature of man" (Raphael 1974: 28). See also MacIntyre (1959) who holds that Hume reasserted the Aristotelian view, whose demise had initially less to with ethical rationalism than to the Protestant notion of the radical depravity of human nature. Who would want place morality on such a rotten foundation? Clearly, on such assumptions nothing could be more wrongheaded than to derive positive moral values on the basis of a study of human nature's "appetites" and desires. Hume, however, objected: "Against the Protestants Hume reasserted the founding of morality on human nature. The attempt to make Hume a defender of the autonomy of ethics is likely to conceal his difference from Kant, whose moral philosophy is, from one point of view, the natural outcome of the Protestant position" (MacIntyre 1959: 467-68). The Humean view also has connections forward in time to a Darwinian metaethics. See Curry's article 'Who's Afraid of the Naturalistic Fallacy?' (2006) for an interesting defense of the Humean and Darwinian view. Curry also offers the following penetrating remark: "Despite Hume's naturalistic approach to ethics, and despite it being the case that Hume's simple logical point about moving 'from is to ought' is entirely neutral with regard to the ontological status of moral values, Hume is widely regarded as having demonstrated a fundamental flaw in naturalistic ethics. How did this happen? Part of the explanation is that Hume's dictum is often presented in terms of the impossibility of moving from 'facts to values'; and that this formulation tends to conflate 'values' and 'oughts'. Let value refer to the first premise of a means-end syllogism, let fact refer to the second premise, and let ought refer to the conclusion. Hume argued, first, for a naturalistic account of value; and, second, that in the absence of values, facts alone are insufficient to arrive at oughts. However, if one presents this second argument - about moving 'from facts to oughts' - in terms of the impossibility of moving 'from facts to values' it can look as if Hume's second argument contradicts his first" (Curry 2006: 237-38).

${ }^{8}$ It should be noted that Cohen regards his own position to be independent of the issue of Hume's law (Cohen 2003: 228-29).

${ }^{9}$ Of course, they already have a precedent in Bernard Williams' ethical thought. For a description of the Humean elements of Williams' ethics, see Greco 2007. Williams discuss the naturalistic fallacy in Williams 2011: ch. 7. Citing the is/ought paragraph he writes: "It has been reasonably doubted whether Hume himself meant by this passage what has subsequently been made of it” (2011: 136). 
10 Machiavelli's own statement on the proper assumption reads: "[I]t is necessary to whoever disposes of a republic and orders law in it to presuppose that all men are bad" (Machiavelli 1998: 15).

11 Hume was also influential in giving Madison and others confidence to reject the classical view that republican government was suitable only for small societies (Haakonssen 1993: 213; Hardin 2007: 152). A full list of the topics in The Federalist Papers in which one may "glimpse" Hume's influence is given by Whelan (2004: 369n108). See also Werner 1991: 164-65, who says that "Madison was a disciple of Hume" and that he "realized that here in America all of Hume's theoretical foundations for a stable, large republic were already present".

12 According to Pocock, this means that Hume had "perhaps fewer" illusions than even Machiavelli (Pocock 1975: 497).

13 One interesting topic, regarding non-ideal theory generally, is Hume's notion of the "circumstances of justice". The idea of "circumstances" was picked up by Rawls, who used it in his theory of justice (Rawls 2005: 126-130). To show that Hume's thoughts on the concept of justice is in tension with how Rawls construes justice would be one way to align Hume's thought with that of present day realists and their critique of Rawls and ideal theory. However, to do this would require us to go into a fairly detailed level of Rawls' theory. For reasons of brevity I can only present the outline of this kind of argument, which has been suggested by a recent critique of Rawls made by Colin Farrelly (2007). The "circumstances" are the fact of limited generosity together with scarcity of resources (this is set out at length in Enquiry: 4 and Treatise, 3.2.2.16). These circumstances are what make conventions of justice necessary in a society. Rawls held that his theory of justice fulfilled the requirements set by the circumstances of justice; that is, he held that his assumptions of a well-ordered society inhabited by fully compliant citizens with a sense of justice did not violate Hume's requirements of a theory of justice. The key point in Colin Farrelly's critique is that Rawls is blind to costs. While "the circumstances of justice" is known by the parties deliberating in the original position, the problem of scarcity doesn't feature in their discussions on the potential principles of justice. Importantly, Rawls make them consider different sets of rights as if their enforcement were costless. How can they be costless? Well, Rawls has already assumed full compliance by citizens, as well as a closed society with no migration. Additionally, he slips in the assumption that in the society in question "reasonably favourable conditions" obtains. Taken together this means that it is merely a matter of political will if for the society to be a liberaldemocratic constitutional regime. On these assumptions Rawls' parties end up with the two principles of justice. Farrelly's point is that they get there only by violating the assumption of moderate scarcity: they can choose Rawls' two principles, and thus reject the principle of utility, only if scarcity is not part of the picture (2007: 848). In that sense Rawls' theory is not consistent with the requirements set by the "circumstances of justice": "By ignoring the realities of noncompliance and scarcity of resources, Rawls' theory of 'justice as fairness' insulates itself from the most pressing concerns that face every real society. The assumption that protecting these 'negative' rights will have no costs might (arguably) be true if we lived in a society with full compliance and abundance of resources. But such an assumption goes beyond what ideal theory is supposed to presuppose - namely, that we be realistic about what the best of foreseeable conditions are. The best foreseeable conditions do not include the possibility of living in a society of saints or transcending moderate scarcity. Such conditions would violate Hume's circumstances of justice. We would not need justice if this kind of utopian society were possible" (Farrelly 2007: 853).

${ }^{14}$ Hume criticize the Tory doctrine more fully in the essay 'Of Passive Obedience'. By criticizing both the Tories and the Whigs, these essays are an example of Hume's general approach of trying to find the middle ground and moderating between the extremes. For comments on that ambition of Hume's writings, see Forbes 1975: 136, 194, 219; Haakonssen 1993: 208-9.

15 Hume also has a more philosophical argument against contract theory. I will leave these arguments to the side, but there essence is the following: To ground obligation to government on a contract is to appeal to promise and promise-keeping. But these are in themselves social conventions, and cannot be appealed to as the base for social or political order. See Essays: 480-81; EPM: Appendix 3.7; Treatise: 3.2 .5 and 3.2.8.5-6; and discussed by many commentators, e.g Rawls 2007: 169; Mackie 1980: 96-97; Hardin 2007: 114, 120; Forbes 1975: 66-67; Buckle \& Castiglione 1991: 460-61.

${ }^{16}$ A very similar remark can be found in History VI: 528.

${ }^{17}$ Perhaps it is correct to say, in response to Hardin's estimation, that Hume at least put an end to Lockean contractarianism in England. This view is held by Rawls, who thinks that "on that evidence, Hume's essay was historically very effective" (Rawls 2007: 170). 
18 The question of the historicity of the supposed contract is of course highly contested. As Lessnoff says, both Hobbes and Locke show "evident signs of uneasiness" on this issue. Especially when it comes to Hobbes one may hold that Hobbes does not believe in an original contract. Rawls says that "In Hobbes there is not, on the whole, an appeal to the past" (Rawls 2007: 160). If understood in this way, as merely supplying reasons for allegiance in terms of each individual's own interests, there is basically no role for the notion of consent in Hobbes thought. Then one can even doubt whether he belongs to the contractarian tradition at all, "he often defies the central elements of contractarian thinking" (Hardin 2007: 119). Be that as it may, it is Locke, not Hobbes, that is the unnamed object of Hume's critique (Rawls 2007: 166). Furthermore, it is not from Hobbes that the contemporary contractarian thought that realists are now criticizing stem. Hobbes" "gunman view of the sovereign [...] makes a mockery of contemporary contractarian paeans to the beauty of consent" (Hardin 2007: 119).

${ }^{19}$ Locke's idea of continual tacit consent seems designed to lessen his theory's dependency on the historicity of the original contract.

${ }^{20}$ On Horton's view the move to hypothetical consent means the transition to a wholly different category of theories of political obligation, namely deontological theories as opposed to the two other main categories: voluntarist and teleological theories.

${ }^{21} \mathrm{He}$ is probably the first thinker to state these game theoretical problems clearly, see Elster 2009: 51-52; Frazer 2010: 77-78; Hardin 2007: 26, 56-57, 230. The key sections in the Treatise are 3.2.2.10 and 3.2.7.8.

22 To be compared with Fukuyama: "Hobbes is famous for his assertion that the state of nature was a state of war of "every man against every man. [...] Hobbes is far closer to the truth [than Rousseau], albeit with the important qualification that violence took place not between isolated individuals but between social groups. Human beings' highly developed social skills and ability to cooperate are not contradicted by the prevalence of violence in both chimp and human societies; rather, they are the precondition for it. [...] The vulnerability of both apes and humans to violence by their fellow species members in turn drives the need for greater social cooperation" (Fukuyama 2011: 72-73). The view that violence impels greater cooperation is likewise crucial in Hume's account: "Government commences more casually and more imperfectly. It is probable, that the first ascendant of one man over multitudes begun during a state of war; where the superiority of courage and of genius discovers itself most visibly, where unanimity and concert are most requisite, and where the pernicious effects of disorder are most sensibly felt. The long continuance of that state, an incident common among savage tribes, enured the people to submission; and if the chieftain possessed as much equity as prudence and valour, he became, even during peace, the arbiter of all differences, and could gradually, by a mixture of force and consent, establish his authority" (Essays: 39-40). This kind of theory ultimately stem from Polybius (Whelan 2009: 62). Hume's views on the progress of society and rise of government were developed through discussions with Adam Smith (Haakonssen 1993: 194; Forbes 1975: 76). The similarity between the two is evident in Smiths' Lectures on Jurisprudence: regarding contract theory and political obligations, see for instance Smith 1978: 316-23, 402-3, 434-35; and regarding different form of social organization and the origins of government, 1978: 200-2, 404-8.

23 These thinkers would have found nothing new in what Fukuyama tells his readers 250 years later: "Everything that modern biology and anthropology tell us about the state of nature suggests the opposite: there was never a period in human evolution when human beings existed as isolated individuals; the primate precursors of the human species had already developed extensive social, and indeed political, skills; and the human brain is hardwired with faculties that facilitate many forms of social cooperation. The state of nature might be characterized as a state of war, since violence was endemic, but the violence was not perpetrated by individuals so much as by tightly bonded social groups. Human beings do not enter into society and political life as a result of conscious, rational decision. Communal organization comes to them naturally, though the specific ways they cooperate are shaped by environment, ideas, and culture" (Fukuyama 2011: 30). The sentimentalist tradition, prevalent in the Scottish enlightenment, consistently stress mankind's natural sociality, for example Shaftesbury and Hutcheson (Frazer 2010: 34; Forbes 1975: 38). 
${ }^{24}$ Whelan supplies a useful summary of all the features of Hume's thought that overlap with those usually associated with classical liberalism: "(1) Self-interested individualism as a methodological principle, and, to a substantial degree, as an assumption about actual motivation in social and political life; (2) a view of politics as an activity centered on attempts to advance diverse interests and on strategies for containing or managing conflict rather than as a quest for social harmony or human perfection; (3) religious and intellectual toleration and openness; (4) enthusiasm for economic growth through secure property rights, commerce, competition, and free markets; and (5) a high valuation on personal liberty, restrained by respect for a similar liberty in others and understood principally as the product of the rule of law and limited constitutional government" (Whelan 2004: 3).

${ }^{25}$ In the essay 'Of the Origin of Government', the very last Hume wrote, he further elaborated the view in the History: "In all governments, there is a perpetual intestine struggle, open or secret, between Authority and Liberty; and neither of them can ever absolutely prevail in the contest. A great sacrifice of liberty must necessarily be made in every government; yet even the authority, which confines liberty, can never, and perhaps ought never, in any constitution, to become quite entire and uncontroulable. [...] In this sense, it must be owned, that liberty is the perfection of civil society; but still authority must be acknowledged essential to its very existence: and in those contests, which so often take place between the one and the other, the latter may, on that account, challenge the preference" (Essays: 40-41).

${ }^{26}$ Mark Philp must be regarded as the leader of the search party (Philp 2007 \& 2010). On Kant's political ethics, see Formosa 2008.

27 Very late in the process I found that Andrew Sabl, a commentator on Hume (2002; 2009), has written a piece on "Harvard School" realism (2011). Sabl briefly points to the relevance of Hume to realism on two issues: One is the eroding of the is/ought distinction (2011: 154-55). The second concern Hume's approach to history which exemplifies a kind of normative theorizing that is in close contact with social and political context rather than being abstracted and applied from above (2011: 166). Significantly, Sabl will in a forthcoming book discuss "the exact mode in which Hume combined agency and situation" in his historical works (2011: 166n26). 


\section{Executive summary}

This paper concern the relation between the movement of realism in contemporary political theory and the social and political thought of David Hume. The general purpose that guides the paper is to show that Hume's political thought is a possible alternative which political theorists of realist persuasion can build on in order to challenge the Kantianism that dominates contemporary political theory. The primary aim is to single out the most important features of Hume's thought which show a similarity to the standpoints and approach of contemporary realists. Four themes are highlighted:

(1) Normativity. The first theme is Hume's general approach to normative theory, which is often subject to a crucial misinterpretation. The standard interpretation of what has come to be called "Hume's law" makes Hume into a defender of the kind of free-standing and rationalistic normative thought which realists are criticizing. In opposition to this interpretation the paper highlights critics arguing that this interpretation does not square with the main characteristics of Hume's philosophy. What is typical of Hume's stance on normative theory is precisely that an empirical study of human nature and social existence is held to be vital. In fact, the is/ought paragraph is the ending of a sustained attack on ethical rationalism. A more credible interpretation of the passage and of Hume in general is suggested, and this interpretation makes Hume an ally of contemporary realists in their critique of Kantian ethical rationalism.

(2) Motivational realism. The second theme concerns the appropriate assumptions that a theorist should hold when considering possible reforms, policies and constitutions. Realists are wary of taking too much for granted when it comes to good will, reasonableness, or sense of public good. They insist that to assume too favorable motivations results in useless and even dangerous political theory. If in fact people's motivations and behavior is more dominated by selfinterest than by reason and moral considerations, then policies derived on the opposite assumption puts us in peril and run a high risk of being corrupted. This line of thought is easily detected throughout Hume's writings, most obviously in his famous maxim on knavery. Hume argues that we would be fools not to judge proposals on the assumption that people will act on self-interest. Furthermore, he disparages proposals that expect "great transformation in the manners of mankind". We must instead take mankind as we find it and devise our institutions and policies on that basis. This is reason for thinking that Hume would share contemporary realists concern over the tendency to assume good faith and full compliance with the principles that the theorist proposes. Theories of deliberative democracy, for instance, often set down precepts such as that everyone should listen to each others argument, not be biased against other citizens and so on. In contrast to this, a realist like William Galston demand that we do the other way around: we better assume that such principles will not be complied with by 
everyone, and we need to construct decision procedures that does not allow such "knavery" to pay off.

(3) Social contract and political obligation. Political authority and legitimacy are central issues for realists, and they question the standard liberal view that consent is a necessary condition for legitimacy. In Hume's time idealistic or moralistic liberal philosophers answered such questions by the use of various social contract theories. It is thus a significant fact that of all the important philosophers of the age, Hume was alone in his rejection of a contractual foundation of political obligation and legitimacy. Not surprisingly, therefore, some interesting parallels can be made to present day realist critiques. One key argument for Hume was that the requirement of consent, which is at the base of all contract theories, has the consequence that probably all regimes are and have always been illegitimate. This reductio ad absurdum argument might not convince everyone, but for realists it would certainly strike a cord. They push a similar line of argument against the standard liberal account of legitimacy. Furthermore, it is suggested that Hume would have objected to the development of the social contract tradition that occurred after his death. Kant reformulated the contract theory, much in response to Hume's critique of Locke, so that it became wholly immune to empirical fact. Thus the contract tradition took a turn to the even more empirically remote kind of theorizing. In any event, it is suggested that in the opposition to the contract tradition one can detect great intellectual affinity between Hume and contemporary realists.

(4) Human sociality and political order. Relatedly, the paper highlights Hume's account of the origins of political order, along with his view on humans as social beings. Hume could on this topic be of interest for realists, it is suggested, since his views seem to have some similarity to Galston's and other realists' attempts to describe what lies at the root of their insistence of the autonomy of politics as a sphere. Galston's suggestion that the root lies in our species' "unscripted sociality" could find historical precedence in Hume's views. While humans are social beings whose existence depends on cooperation, the forms of such cooperation is not supported by strong natural instincts. It is the possibility of "defection" that makes government a necessity. To a much greater extent than Hobbes or Locke, Hume maintains that humans are beings who by nature are social, and he differs in holding that human societies without government are a genuine state of human existence. At the same time his account of how government arise shows a similarity to the "unscripted" character of human sociality. The transition to a large-scale society means that it becomes possible to defect from cooperative conventions without incurring any social costs. This creates an imperative need for the institutionalizing of a mechanism that detect and punish transgressors and thus maintain the order which social pressure no longer can uphold.

Moving beyond these realist themes, the final chapter discusses the possibility of combining realism with liberalism. The realists' emphasis on the value of social and political order means that a commitment to liberalism implies a balancing act. Since the progressive reforms that a liberal would recommend are sometimes liable to upset the established order, the realist must face the task of making 
judgments on what the historical circumstances allow. There is a risk that the thinker's liberalism is overrun by the realist and conservative insistence on the need for political stability. These problems realists must face today, and they mirror the struggle Hume was engaged in in his History of England. Hume attempts to make fair historical judgments on past political actors and regimes in terms of the progress achieved and the need to maintain order. It is proposed that realists may find it worthwhile to study Hume's principles for making such judgments. 


\section{References}

Barry, Brian (1989), Theories of Justice (London: Harvester Wheatsheaf).

Buckle, Stephen and Castiglione, Dario (1991), 'Hume's Critique of the Contract Theory', History of Political Thought, 12 (3), 457-80.

Cohen, G. A. (2003), 'Facts and Principles', Philosophy \& Public Affairs, 31 (3), 211-45.

Cohon, Rachel (2008), Hume's Morality (Oxford: Oxford University Press).

Coventry, Angela and Sager, Alexander (2011), 'Hume and Contemporary

Political Philosophy', Western Political Science Association 2011 Annual Meeting.

Curry, Oliver (2006), 'Who's Afraid of the Naturalistic Fallacy?', Evolutionary Psychology, 4, 234-47.

Elster, Jon (2009), Alexis de Tocqueville: the First Social Scientist (Cambridge; New York: Cambridge University Press).

Farrelly, Colin (2007), 'Justice in Ideal Theory: A Refutation', Political Studies, 55 (4), 844-64.

Formosa, Paul (2008), "All Politics Must Bend Its Knee Before Right': Kant on the Relation of Morals to Politics', Social Theory and Practice, 34 (2), 157-81.

Frazer, Michael L. (2009), 'Review of J. G. A. Pocock's 'Political Thought and History: Essays on Theory and Method", Notre Dame Philosophical Reviews. $<$ http://ndpr.nd.edu/news/24213-political-thought-and-history-essays-ontheory-and-method/>, accessed 2011.11.04.

Frazer, Michael L. (2010), The Enlightenment of Sympathy: Justice and the Moral Sentiments in the Eighteenth Century and Today (Oxford; New York: Oxford University Press).

Fukuyama, Francis (2011), The Origins of Political Order (New York: Farrar, Straus and Giroux).

Galston, William A. (2004), 'On the Rapproachment between Political Philosophy and Empirical Inquiry: A Comment on Rogers Smith', in Edward D. Mansfield and Richard Sisson (eds.), The Evolution of Political Knowledge: Theory and Inquiry in American Politics (Columbus: Ohio State University Press).

Galston, William A. (2009), 'Moral Pluralism and Liberal Democracy: Isaiah Berlin's Heterodox Liberalism', Review of Politics, 71 (1), 85-99.

Galston, William A. (2010), 'Realism in Political Theory', European Journal of Political Theory, 9 (4), 385-411.

Geuss, Raymond (2008), Philosophy and Real Politics (Princeton: Princeton University Press).

Greco, Lorenzo (2007), 'Humean Reflections in the Ethics of Bernard Williams', Utilitas, 19 (03), 312-25.

Gunnell, John G. (1982), 'Interpretation and the History of Political Thought: Apology and Epistemology', The American Political Science Review, 76 (2), 317-27. 
Haakonssen, Knud (1993), 'The Structure of Hume's Political Theory', in David Fate Norton (ed.), The Cambridge Companion to David Hume (Cambridge: Cambridge University Press).

Hampshire, Stuart (1991), 'Nationalism', in Edna Ullman-Margalit and Avishai Margalit (eds.), Isaiah Berlin: A Celebration (Chicago: University of Chicago Press).

Hardin, Russell (2007), David Hume: Moral \& Political Theorist (Oxford: Oxford University Press).

Hendrix, Burke A. (2010), 'Political Theorists as Dangerous Social Actors', Critical Review of International Social and Political Philosophy, 1-21.

Honig, Bonnie and Stears, Marc (2011), 'The New Realism: from Modus Vivendi to Justice', in Jonathan Floyd and Marc Stears (eds.), Political Philosophy versus History? Contextualism and Real Politics in Contemporary Political Thought (Cambridge: Cambridge University Press), 177-205.

Horton, John (1992), Political Obligation (London: Macmillan).

Horton, John (2010), 'Realism, liberal moralism and a political theory of modus vivendi', European Journal of Political Theory, 9 (4), 431-48.

Hume, David (1983a), The History of England. Volume I (Indianapolis: Liberty Fund).

Hume, David (1983b), The History of England. Volume VI (Indianapolis: Liberty Fund).

Hume, David (1987), Essays: Moral, Political, and Literary (Indianapolis: Liberty Classics).

Hume, David (1998), An Enquiry Concerning the Principles of Morals (The Clarendon Edition; Oxford: Oxford University Press).

Hume, David (2007), A Treatise of Human Nature (The Clarendon Edition; Oxford: Oxford University Press).

Hume, David (2011), The Letters of David Hume Volume I: 1727-1765, ed. J.Y.T. Greig (Oxford: Oxford University Press).

Kant, Immanuel (1991), Political Writings (Cambridge Texts in the History of Political Thought; Cambridge: Cambridge University Press).

Keene, Edward (2005), International Political Thought (Cambridge: Polity Press).

Lessnoff, Michael (1990), Social Contract Theory (New York: New York University Press).

Locke, John (2002), The Second Treatise of Government: and A Letter Concerning Toleration (Mineola, NY: Dover Publications).

Machiavelli, Niccolo (1998), Discourses on Livy (Chicago: The University of Chicago Press).

MacIntyre, A. C. (1959), 'Hume on "Is" and "Ought"', The Philosophical Review, 68 (4), 451-68.

Mackie, John (1980), Hume's Moral Theory (London: Routledge \& Kegan Paul).

Miller, David and Dagger, Richard (2003), 'Utilitarianism and Beyond: Contemporary Analytical Political Theory', in Terence Ball and Richard Bellamy (eds.), The Cambridge History of Twentieth-Century Political Thought (Cambridge: Cambridge University Press). 
Newey, Glen (2010), 'Two Dogmas of Liberalism', European Journal of Political Theory, 9 (4), 449-65.

North, Richard (2010), 'Political realism: Introduction', European Journal of Political Theory, 9 (4), 381-84.

Pasquino, Pasquale (1996), 'Political Theory, Order, and Threat', in Russell Hardin and Ian Shapiro (eds.), Political Order (Nomos; New York: New York University Press).

Peter, Fabienne (2010), 'Political Legitimacy', in Edward N. Zalta (ed.), The Stanford Encyclopedia of Philosophy (Summer 2010 Edition).

Philp, Mark (2007) Political Conduct (Cambridge, MA: Harvard University Press).

Philp, Mark (2008), 'Political Theory and History', in Marc Stears and David Leopold (eds.), Political Theory: Methods and Approaches (Oxford: Oxford University Press).

Philp, Mark (2010), 'What is to be done? Political theory and political realism', European Journal of Political Theory, 9 (4), 466-84.

Pocock, J. G. A. (1975), The Machiavellian Moment. Florentine Political Thought and the Atlantic Republican Tradition (Princeton: Princeton University Press).

Pocock, J. G. A. (2009), Political Thought and History (Cambridge: Cambridge University Press).

Raphael, D. D. (1974), 'Hume's Critique of Ethical Rationalism', in William B. Todd (ed.), Hume and the Enlightenment (Edinburgh: Edinburgh University Press), 14-29.

Rawls, John (2005), A Theory of Justice (Cambridge, MA: Belknap Press Harvard University Press).

Rawls, John (2007), Lectures on the History of Political Philosophy (Cambridge, MA: The Belknap Press of Harvard University Press).

Riley, Patrick (1973), 'On Kant as the Most Adequate of the Social Contract Theorists', Political Theory, 1 (4), 450-71.

Rossi, Enzo (2010), 'Review: Reality and Imagination in Political Theory and Practice: On Raymond Geuss' realism', European Journal of Political Theory, 9 (4), 504-12.

Sabl, Andrew (2002), 'When Bad Things Happen from Good People (and ViceVersa): Hume's Political Ethics of Revolution', Polity, 35 (1), 73-92.

Sabl, Andrew (2009), 'The Last Artificial Virtue. Hume on Toleration and Its Lessons', Political Theory, 37 (4), 511-38.

Sabl, Andrew (2011), 'History and Reality: Idealist Pathologies and 'Harvard School' Remedies', in Jonathan Floyd and Marc Stears (eds.), Political Philosophy versus History? Contextualism and Real Politics in Contemporary Political Thought (Cambridge: Cambridge University Press), 151-76.

Sleat, Matt (2007), 'Making Sense of our Political Lives - On the Political Thought of Bernard Williams', Critical Review of International Social and Political Philosophy, 10 (3), 389-98.

Sleat, Matt (2010), 'Bernard Williams and the Possibility of a Realist Political Theory', European Journal of Political Theory, 9 (4), 485-503. 
Sleat, Matt (2011), 'Liberal Realism: A Liberal Response to the Realist Critique', The Review of Politics, 73 (03), 469-96.

Smith, Adam (1982), Lectures on Jurisprudence (Indianapolis: Liberty Fund).

Stears, Marc (2007), 'Liberalism and the Politics of Compulsion', British Journal of Political Science, 37 (03), 533-53.

Stewart, John B. (1963), The Moral and Political Philosophy of David Hume (New York \& London: Columbia University Press).

Werner, John M. (1991), 'David Hume and America', in Donald W. Livingston and Marie Martin (eds.), Hume as Philosopher of Society, Politics, and History (Rochester, NY: University of Rochester Press).

Whelan, Frederick G. (2004), Hume and Machiavelli: Political Realism and Liberal Thought (Lanham, Md.: Lexington Books).

Whelan, Frederick G. (2009), Enlightenment Political Thought and Non-Western Societies (New York: Taylor \& Francis).

Williams, Bernard (2005), In the Beginning Was the Deed: Realism and Moralism in Political Argument (Princeton, N.J.: Princeton University Press).

Williams, Bernard (2011), Ethics and the Limits of Philosophy (London \& New York: Routledge Classics).

Wolff, Jonathan (2006), An Introduction to Political Philosophy (Oxford: Oxford University Press).

Wootton, David (1993), 'David Hume, 'the historian", in David Fate Norton (ed.), The Cambridge Companion to Hume (Cambridge: Cambridge University Press), 281-312. 